\title{
A nitrogen footprint model to help consumers understand their role in nitrogen losses to the environment
}

\author{
Allison M. Leach ${ }^{\text {a }}$ \\ James N. Galloway ${ }^{a}$ \\ Albert Bleeker ${ }^{b}$ \\ Jan Willem Erisman ${ }^{\text {b }}$ \\ Richard Kohn ${ }^{\mathrm{c}}$ \\ Justin Kitzes $^{\text {d }}$ \\ ${ }^{a}$ Environmental Sciences Department, University of Virginia, USA \\ ${ }^{b}$ Energy Research Center of the Netherlands, Netherlands \\ ${ }^{c}$ Department of Animal and Avian Sciences, University of Maryland, USA \\ ${ }^{d}$ Department of Environmental Science, Policy and Management, University of California, USA
}

Published in Environmental Development 1 (2012) 40-66 
Provided for non-commercial research and education use. Not for reproduction, distribution or commercial use.

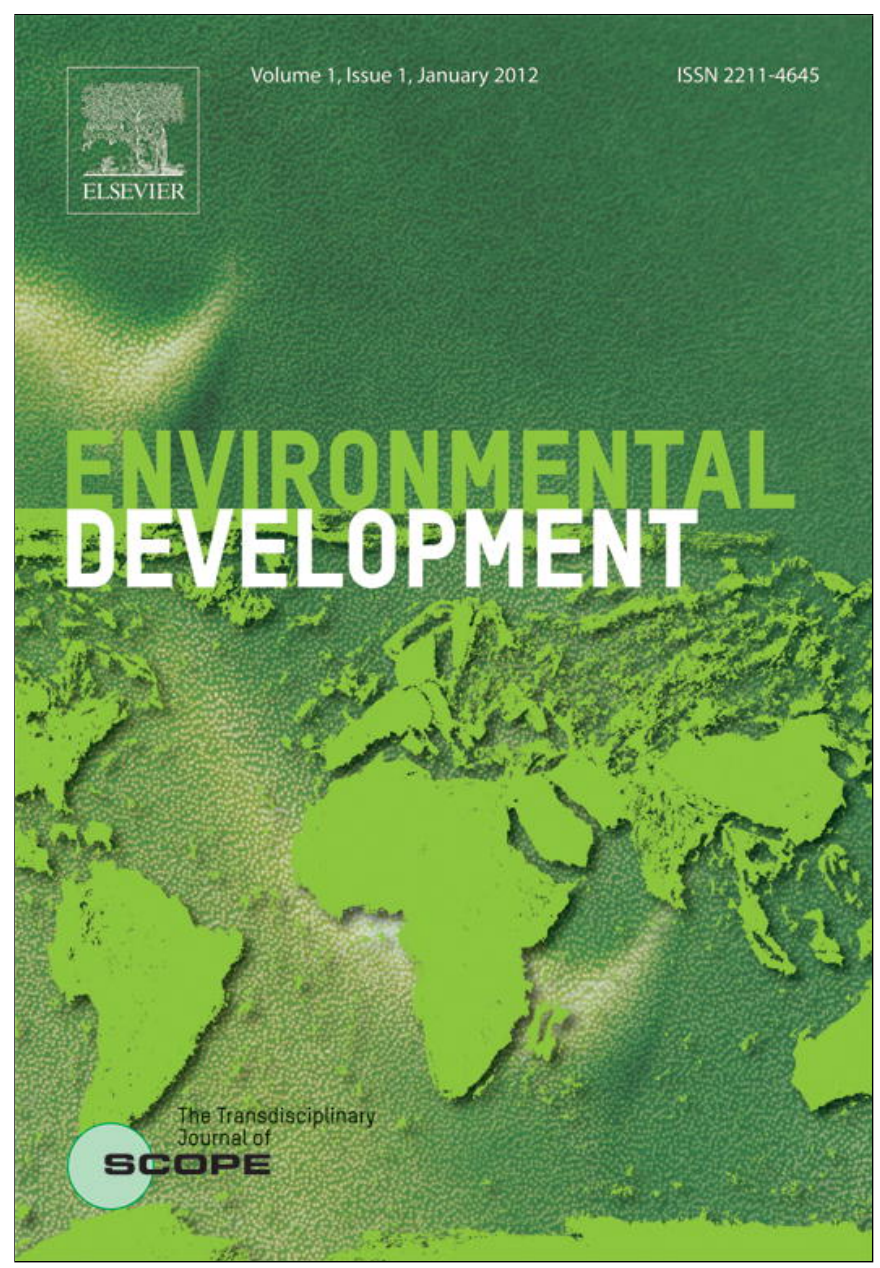

This article appeared in a journal published by Elsevier. The attached copy is furnished to the author for internal non-commercial research and education use, including for instruction at the authors institution and sharing with colleagues.

Other uses, including reproduction and distribution, or selling or licensing copies, or posting to personal, institutional or third party websites are prohibited.

In most cases authors are permitted to post their version of the article (e.g. in Word or Tex form) to their personal website or institutional repository. Authors requiring further information regarding Elsevier's archiving and manuscript policies are encouraged to visit:

http://www.elsevier.com/copyright 


\title{
A nitrogen footprint model to help consumers understand their role in nitrogen losses to the environment
}

\author{
Allison M. Leach ${ }^{\mathrm{a}, *}$, James N. Galloway ${ }^{\mathrm{a}}$, Albert Bleeker ${ }^{\mathrm{b}}$, \\ Jan Willem Erisman ${ }^{b}$, Richard Kohn ${ }^{\mathrm{c}}$, Justin Kitzes ${ }^{\mathrm{d}}$ \\ a Environmental Sciences Department, University of Virginia, 291 McCormick Road, PO Box 400123, Charlottesville, VA 22904, USA \\ ${ }^{\mathrm{b}}$ Energy Research Center of the Netherlands, PO Box 1, 1755ZG Petten, Netherlands \\ ${ }^{\mathrm{c}}$ Department of Animal and Avian Sciences, University of Maryland, Bldg 142, College Park, MD 20742, USA \\ d Department of Environmental Science, Policy and Management, University of California, 130 Mulford Hall \#3114, Berkeley, \\ CA 94720, USA
}

\section{A R T I C L E I N F O}

\section{Article history:}

Received 1 August 2011

Accepted 1 August 2011

\section{Keywords:}

Nitrogen

Footprint

Food production

Energy usage

Nitrogen cascade

Environment

\begin{abstract}
A B S T R A C T
The human use of reactive nitrogen $\left(\mathrm{N}_{\mathrm{r}}\right)$ in the environment has profound beneficial and detrimental impacts on all people. Its beneficial impacts result from food production and industrial application. The detrimental impacts occur because most of the $\mathrm{N}_{\mathrm{r}}$ used in food production and the entire amount of $\mathrm{N}_{\mathrm{r}}$ formed during fossil fuel combustion are lost to the environment where it causes a cascade of environmental changes that negatively impact both people and ecosystems.

We developed a tool called $\mathrm{N}$-Calculator, a nitrogen footprint model that provides information on how individual and collective action can result in the loss of $\mathrm{N}_{\mathrm{r}}$ to the environment. The NCalculator focuses on food and energy consumption, using average per capita data for a country. When an individual uses the $\mathrm{N}$-Calculator, the country average is scaled based on the individual's answers to questions about resource consumption.

$\mathrm{N}$ footprints were calculated for the United States and the Netherlands, which were found to be $41 \mathrm{~kg} \mathrm{~N} /$ capita/yr and $24 \mathrm{~kg} \mathrm{~N} / \mathrm{capita} / \mathrm{yr}$, respectively. For both countries, the food portion of the footprint is the largest, and the food production $\mathrm{N}$ footprints are greater than the food consumption $\mathrm{N}$ footprints.

The overarching message from the $\mathrm{N}$-Calculator is that our lifestyle choices, and especially our food consumption, have major
\end{abstract}

\footnotetext{
* Corresponding author. Tel.: +1 434924 1303; fax: +1 4349822137.

E-mail addresses: aml4x@virginia.edu (A.M. Leach), jng@virginia.edu (J.N. Galloway), a.bleeker@ecn.nl (A. Bleeker), erisman@ecn.nl (J.W. Erisman), rkohn@umd.edu (R. Kohn), jkitzes@berkeley.edu (J. Kitzes).
} 
impacts on the $\mathrm{N}_{\mathrm{r}}$ losses to the environment. Communicating this message to all of the stakeholders (the public, policymakers, and governments) through tools like the $\mathrm{N}$-Calculator will help reduce $\mathrm{N}_{\mathrm{r}}$ losses to the environment.

(c) 2012 Elsevier B.V. All rights reserved.

\section{Introduction}

The human use of reactive nitrogen $\left(\mathrm{N}_{\mathrm{r}}\right.$, all nitrogen species except $\left.\mathrm{N}_{2}\right)$ in the environment has profound beneficial and detrimental impacts on all people. Agricultural uses, including both food production and consumption, contribute the most $\mathrm{N}_{\mathrm{r}}$ to the global environment; the burning of fossil fuels is the next biggest contributor. The beneficial impacts of the agricultural use of $\mathrm{N}_{\mathrm{r}}$ are related to food production using nitrogen fertilizer and human-enhanced biological nitrogen fixation. These two processes provide the $\mathrm{N}_{\mathrm{r}}$ to sustain about half of the world's population (Erisman et al., 2008). The detrimental impacts result because most of the $\mathrm{N}_{\mathrm{r}}$ used in food production and the entire amount of $\mathrm{N}_{\mathrm{r}}$ formed during fossil fuel combustion are lost to the environment.

Once lost to the environment, the nitrogen moves through the Earth's atmosphere, forests, grasslands, and waters causing a cascade of environmental changes that negatively impact both people and ecosystems. These changes include smog, acid rain, forest dieback, coastal 'dead zones', biodiversity loss, stratospheric ozone depletion, and an enhanced greenhouse effect (Galloway et al., 2003, 2008). The disruption of the $\mathrm{N}$ cycle and its impacts necessitate measures to optimize food production and energy use while minimizing the effects. Therefore policies, measures, and behavioral changes are essential. Here we describe tools that can support policymakers, stakeholders, producers, and consumers in that process.

\subsection{Communicating the $N$ story}

Of all the chemical elements, nitrogen is one whose abundance has been increased the most by human activity (Erisman et al., 2008). Globally, humans contribute about twice the amount of nitrogen to the environment as do all the natural terrestrial processes; on a regional basis it can be many-fold more (e.g., US, 5-fold (United States Environmental Protection Agency, 2011); Europe, 4-fold (Sutton et al., 2011)). In contrast, human activity contributes 5-10\% of $\mathrm{CO}_{2}$ emissions; natural processes contribute the remainder (Le Quéré, 2010).

Over the past decade, there have been significant advances in our scientific understanding of the magnitude and consequences of the human alteration of the nitrogen cycle. With these scientific advances, and a much better understanding of how to decrease the negative impacts of nitrogen without impacting the ability to produce food and use energy, we feel it is appropriate to address the challenge of communication and to help consumers and policymakers minimize their role in the disruption of the $\mathrm{N}$ cycle and the resulting environmental consequences. We plan to do this by means of a collection of tools brought together in a system called N-PRINT (Fig. 1). Ultimately, $\mathrm{N}$-PRINT will be able to describe how $\mathrm{N}_{\mathrm{r}}$ is lost to the environment and its resulting impacts due to individual (consumer) and collective (producers and society) consumption behavior and the ways in which policy can have an effect on these losses.

In this paper we will focus on the $\mathrm{N}$-Calculator, which is a per capita $\mathrm{N}$ footprint model that defines an $\mathrm{N}$ footprint as the total amount of $\mathrm{N}_{\mathrm{r}}$ that is lost to the environment due to individual's consumption of food and energy. The N-Calculator provides an integrated approach that takes into account not only the food and energy consumed by individuals, but also the "up-stream" processes that release $\mathrm{N}_{\mathrm{r}}$ to the environment by virtue of the production of the food, energy, goods, and services that individuals use.

\subsection{The footprint concept and existing tools}

The 'footprint' concept has been developed over the last decade to serve as a metric of the single or collective impacts of people on the environment, relative to the capacity of the planet to support 


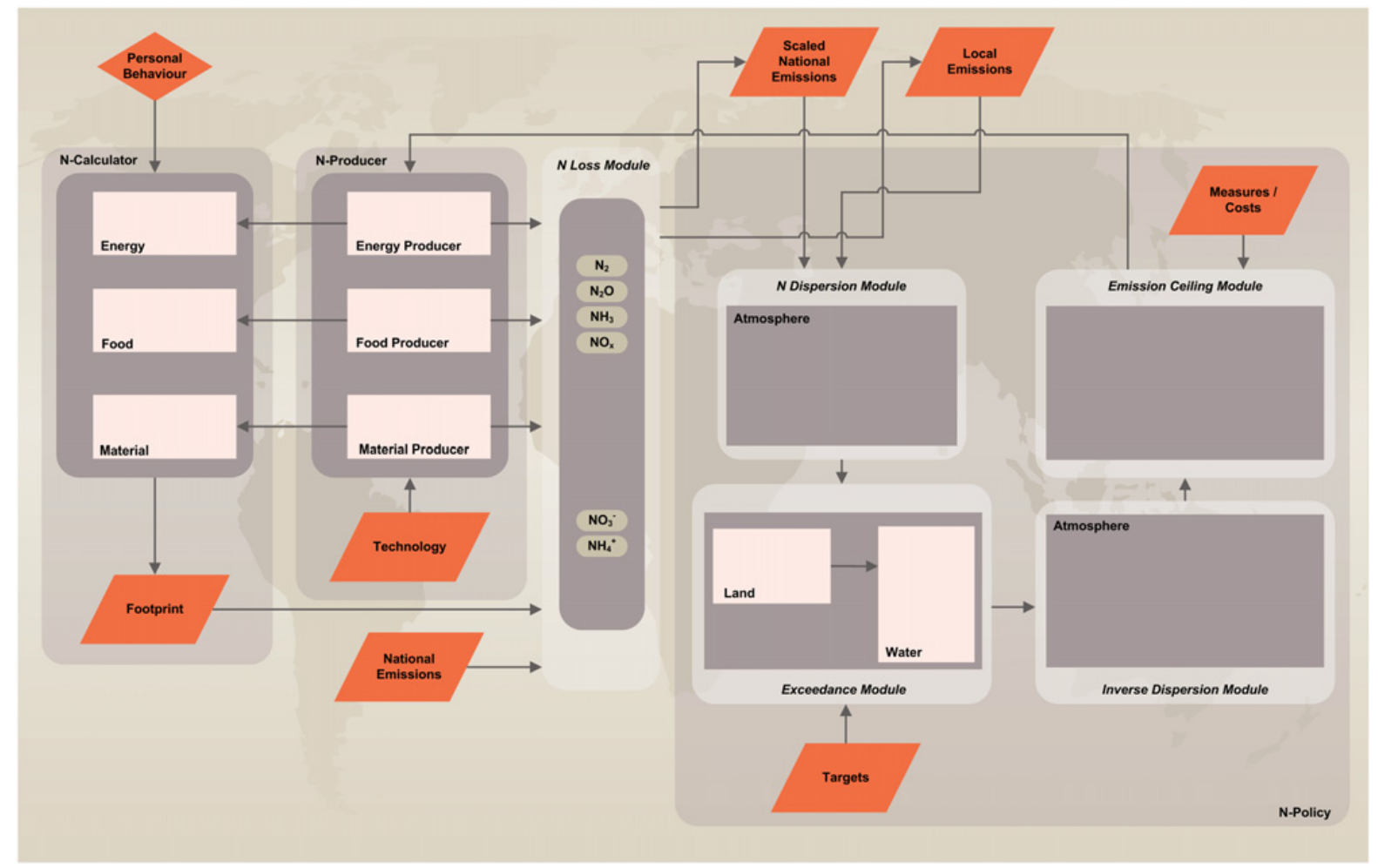

Fig. 1. Schematic of the N-PRINT system: N-Calculator calculates the consumer footprint; N-Producer calculates the footprint of producers (e.g., farmers); and N-Policy calculates the effect of measures and policies on the $\mathrm{N}$ cycle.

those people. There are a number of existing footprint calculators, with The Ecological Footprint being one of the earliest and the most well known with components like energy, food and fiber, timber and paper, and built-up land (Wackernagel et al., 1999, 2002; Global Footprint Network, 2011).

Several groups have examined $\mathrm{N}_{\mathrm{r}}$ flows associated with the use of food and energy by people and regions (e.g., cities, nations). For example, the Chesapeake Bay Foundation in the US has a calculator (Chesapeake Bay Foundation: Your Bay Footprint, 2011) that estimates a household's contribution to $\mathrm{N}_{\mathrm{r}}$ inputs to the Bay resulting from energy use, sewage production, and lawn fertilizer usage. A much more specific calculator has been prepared to estimate $\mathrm{N}, \mathrm{C}$, and $\mathrm{P}$ fluxes in 360 household ecosystems in the Minneapolis-Saint Paul, Minnesota (USA) urban region. Fissore et al. (2011) found that $\mathrm{N}_{\mathrm{r}}$ fluxes into the households were dominated by human diet, lawn fertilizer applications and surface transportation, which together accounted for $\sim 85 \%$ of total household $\mathrm{N}_{\mathrm{r}}$ inputs.

In a life-cycle analysis Xue and Landis (2010) examined the $\mathrm{N}$ and P eutrophication potential of food consumption patterns. They showed that different food groups exhibit a highly variable nitrogen-intensity. On average, red meat and dairy products require much more nitrogen than cereals/carbohydrates. An important point they make is that the ranking of foods' nitrogen footprints is not consistent with their carbon footprints. For example, dairy products and chicken/eggs have high nitrogen footprints but low carbon footprints.

Most recently, Galli et al. (2011) have clustered a suite of indicators (ecological, carbon, water; the "Footprint Family") to track human pressure on the planet. The work was developed under the One Planet Economy Network: Europe (OPEN:EU) project, funded by the 7th Framework Program in the European Commission, and builds on the premise that no single indicator per se is able to comprehensively monitor human impact on the environment, but indicators rather need to be used and interpreted jointly. As they note in the paper, to better track the environmental impacts of production and consumption activities and assess tradeoffs, the Footprint Family could thus benefit from the inclusion in the suite of additional footprint-type of indicators such as 'nitrogen'. In that regard, one of the objectives of this paper is to provide the methodology behind the nitrogen footprint to make it easier to integrate into the Footprint Family. 


\subsection{Objectives}

The objectives of this paper are (1) to provide background on the scientific approaches in model development and explain the methodology of the N-Calculator and (2) to present the nitrogen footprint of the United States and the Netherlands.

\section{Material and methods}

\subsection{Average per capita country nitrogen footprints}

We define a nitrogen footprint as the total amount of $\mathrm{N}_{\mathrm{r}}$ released to the environment as a result of an entity's resource consumption, expressed in total units of $\mathrm{N}_{\mathrm{r}}$. The $\mathrm{N}$-Calculator focuses on four main areas of consumption: food, housing, transportation, and goods and services. The $\mathrm{N}$ footprint consists of the $\mathrm{N}$ embodied in food consumption and production as well as the $\mathrm{NO}_{x}$ emitted by fossil fuel combustion. The $\mathrm{N}$ footprint of each of the areas of consumption is calculated using average per capita data for a country, allowing for the calculation of a country's average per capita $\mathrm{N}$ footprint as well as the total $\mathrm{N}$ footprint for the country. This average footprint is then scaled appropriately when individuals answer questions about their personal resource consumption (Table 1).

In general the following equation holds (with electricity use as an example):

$$
F P_{\text {ind }}=F P_{\text {avg }} \times E U_{\text {ind }} / E U_{\text {avg }}
$$

where $F P_{\text {ind }}$ is the individual footprint (in this case for electricity use), $F P_{\text {avg }}$ the average per capita footprint for a country, $E U_{\text {ind }}$ the individual electricity use, and $E U_{a v g}$ the average per capita electricity use for a country.

This equation format can then be used for each component of an $\mathrm{N}$ footprint. The sum of the $\mathrm{N}$ footprints of each component within a sector (e.g. food, housing, transportation, and goods and services) provides the $\mathrm{N}$ footprint by sector, and the sum of the sectors provides the total $\mathrm{N}$ footprint of an individual.

Below, a more detailed description of the methodology of each sector of the N-Calculator is presented. The sectors are broken up into food (food consumption and production) and energy (housing, transportation, and goods and services).

Table 1

Overview of the $\mathrm{N}$-Calculator questions for scaling the national average $\mathrm{N}$ footprints.

\begin{tabular}{ll}
\hline Topic & Question \\
\hline Food & $\begin{array}{l}\text { 1. How many times a week do you consume different food types? Food categories are the } \\
\text { following: poultry, pigmeat, beef, fish and seafood, milk, cheese, eggs, cereals, rice, vegetables, } \\
\text { beans and other legumes, starchy roots, nuts, stimulants, and alcoholic beverages }\end{array}$ \\
2. Is your house attached to a municipal sewer system with tertiary sewage treatment? \\
Energy \\
$\begin{array}{ll}\text { 1. How many kWh of electricity does your household use each month? } \\
\text { 2. How much natural gas does your household use to heat your home and to cook with } \\
\text { 3. How month? }\end{array}$ \\
$\begin{array}{l}\text { 1. How many hours do you fly each year? } \\
\text { 2. How far do you travel by bus or rail each week? } \\
\text { 3. How far do you travel by car each week? } \\
\text { 4. What kind of car do you drive? }\end{array}$ \\
\begin{tabular}{l} 
1. How would you describe your personal spending on goods and services? \\
\hline
\end{tabular}
\end{tabular}

\footnotetext{
a Other minor food categories were accounted for in the N-Calculator, but user questions are only asked about the categories listed above.
} 


\subsection{Food nitrogen footprint}

The calculation of a food nitrogen footprint consists of two essential parts: food consumption and food production.

\subsubsection{Food consumption}

Calculating a food consumption $\mathrm{N}$ footprint requires data on the average per capita consumption of food and the $\mathrm{N}$ content of food. Databases available from the UN Food and Agriculture Organization (FAO) provide per capita food and protein supply data, by food type (Food and Agriculture Organization of the United Nations Statistics, 2011). While individual countries often have their own data (e.g. the Department of Agriculture in the United States), this study utilized the FAO databases because they allow for comparisons among countries.

To calculate the food consumption $\mathrm{N}$ footprint, country specific per capita protein supply data were recorded from the FAO database by food category, including poultry, pork, beef, fish and seafood, milk, cheese, eggs, animal fats, offals, mutton, goat meat, other meat, cereals, rice, vegetables, fruits, beans and other legumes, starchy roots, nuts, stimulants, alcoholic beverages, oilcrops, spices, sugar and sweeteners, sugarcrops, and vegetable oils.

Food supply data were also recorded and were later used to estimate portion sizes. It is important to note that the protein supply data were used directly to calculate an $\mathrm{N}$ footprint, rather than using the food consumption data and independent estimates of the protein content of the food items. This was done because the FAO reports foods in their whole, uncooked form, including inedible items like bones.

The protein (or food) supply describes the amount of protein available for consumption, and not necessarily the amount of protein consumed, because it does not account for food waste. The amount of protein actually consumed was calculated by subtracting out food waste, which accounts for all the food losses that occur after a food product is ready and available for consumption, including waste at the retailer, foodservice, and consumer levels. Kantor et al. (1997) provide estimates of food waste by food type. The amount of nitrogen consumed was then determined using the calculated value for protein consumption and the knowledge that nitrogen makes up $16 \%$ of protein by mass (Fig. 2A).

Because the average adult does not accumulate nitrogen as muscle mass, we assumed that all nitrogen consumed is excreted and ultimately released to the environment as human waste. The exception is the use of advanced sewage treatment with nutrient removal technology that denitrifies about $90 \%$ the reactive nitrogen in the human waste (Gorecki and Melcer, 2006). When an $\mathrm{N}$-Calculator is developed for a specific country, the availability of advanced sewage treatment is evaluated and considered when determining the average condition.

\subsubsection{Food production}

The food production $\mathrm{N}$ footprint was then calculated (Fig. 2B). We refer to this nitrogen as Virtual N (Galloway et al., 2007; Burke et al., 2008), and it is any nitrogen that was used in the food production process and is not in the food product that is consumed. More specifically, Virtual $\mathrm{N}$ includes all $\mathrm{N}_{\mathrm{r}}$ losses related to an initial investment of nitrogen fertilizer into a system, such as fertilizer not incorporated into the plant, crop residue not part of the food product, feed not incorporated into the animal product, and all of the plant or animal products that are lost in processing and food preparation. Once all of the inputs and releases are summed, the nitrogen consumed as food can be subtracted out; the remaining amount is the Virtual N. In this case, Virtual $\mathrm{N}$ for food does not include the $\mathrm{N}_{\mathrm{r}}$ released to the environment as a result of transportation or other energy use during the food production process; this $\mathrm{N}_{\mathrm{r}}$ was calculated separately, and the procedure is described in Section 2.3.

Different food products demand different amounts of nitrogen to create the consumable food product. There are substantial differences both between plant and animal products and within plant (e.g. vegetable vs. cereals) and animal (e.g. milk vs. beef) products. In that regard, both vegetable products and animal products start with the same procedure to calculate the $\mathrm{N}_{\mathrm{r}}$ released as a result 


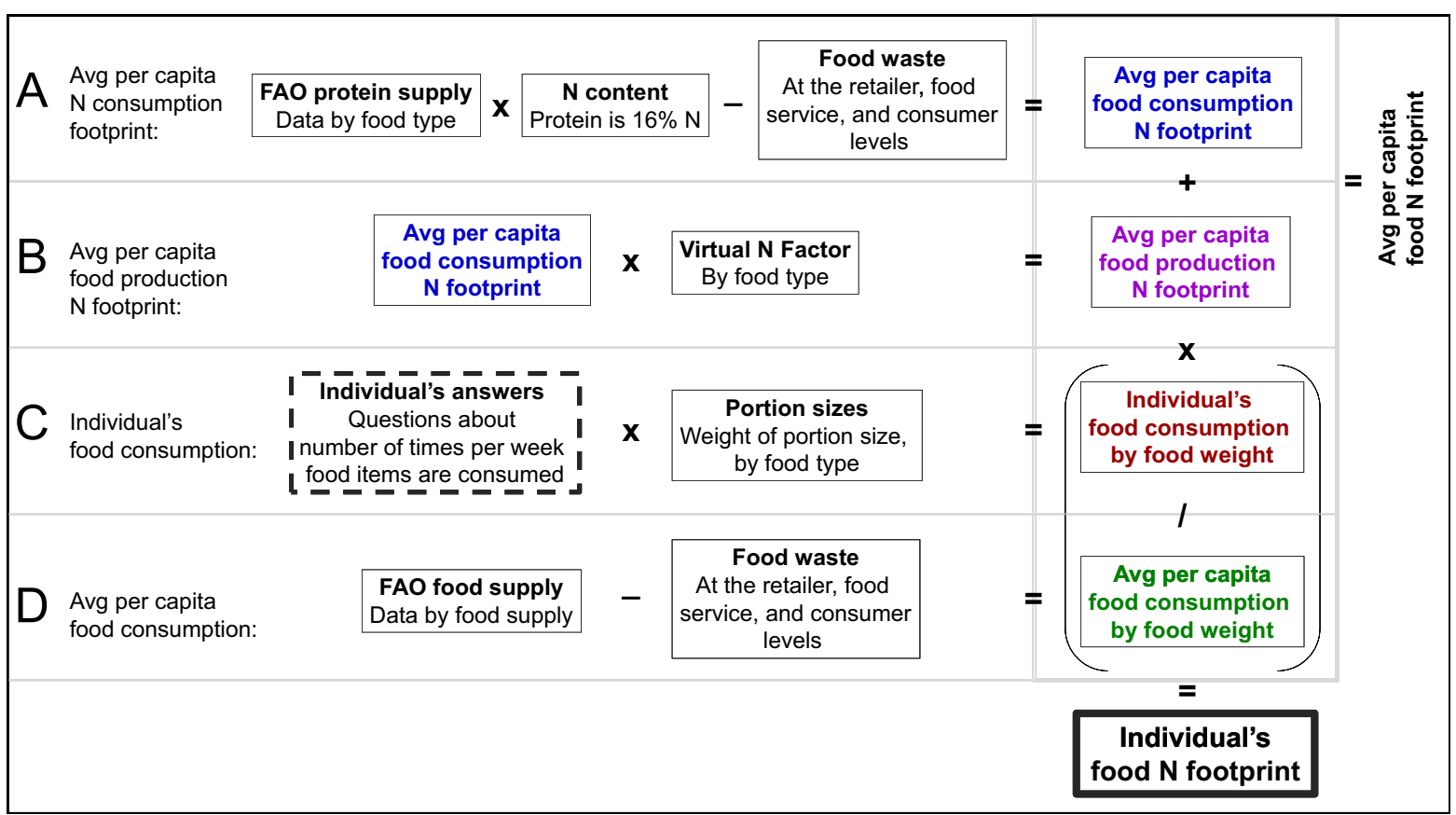

Fig. 2. Calculation schematic for the nitrogen footprint for food. This figure explains the calculation of: (A) the average per capita food consumption $\mathrm{N}$ footprint, (B) the average per capita food production $\mathrm{N}$ footprint, (C) an individual's food consumption by food weight, and (D) the average per capita food consumption, by weight, in the country. It is then shown how all of this information is used to find both a total average per capita food $\mathrm{N}$ footprint and an individual's total food $\mathrm{N}$ footprint. Notes: (1) This figure assumes the required scaling to estimate an annual $\mathrm{N}$ footprint; (2) this figure is in terms of calculations by food type, but assumes the summation of all food types to find the total food $\mathrm{N}$ footprint; and (3) the only input required by an individual is the dashed box.

of growing a crop, but the animal product calculations extend through the production process of the actual animal.

We calculated Virtual $\mathrm{N}$ by relating the units of $\mathrm{N}_{\mathrm{r}}$ released to the environment per unit of $\mathrm{N}_{\mathrm{r}}$ consumed. Referred to as Virtual N Factors, we have estimated these factors for the following major food categories: poultry, pork, beef, milk, vegetables, starchy roots, beans, and grains. For other food categories, we assigned the available Virtual N Factor with the most similar food production process.

The food production process for each of these major food categories was analyzed at each stage of food production. Fig. 3 conceptualizes these food production stages by describing the basic production process for vegetable and animal products, using corn and beef as the respective examples. Cattle are fed corn and additional feeds (forage, soybean meal, byproducts), which are produced and used in aggregate, as exemplified in the beef example. The crop uptake factors used here are higher than typically cited values (Raun and Johnson, 1999; Balasubramanian et al., 2004; Galloway and Cowling, 2002) because the factors used in this analysis describe apparent crop uptake, or the total $\mathrm{N}_{\mathrm{r}}$ taken up by the entire crop (including discarded residues) under optimal conditions. A more detailed description of each step can be found in the online supplementary material.

For each of the steps of food production, 6 different parameters were considered: Available $\mathrm{N}, \%$ of previous $\mathrm{N}$ available, $\mathrm{N}$ waste produced, \% $\mathrm{N}$ recycled, $\mathrm{N}$ recycled, and $\mathrm{N}$ loss. Each of these stages describes the total $\mathrm{N}_{\mathrm{r}}$, regardless of its form. These parameters track what happens to the nitrogen at each stage of food production. They consider, respectively, how much $\mathrm{N}_{\mathrm{r}}$ is available in the food product at each stage, how much is lost as waste, how much of the waste is recycled back into the system, and how much of the waste is lost to the environment. Each of these parameters and their associated calculations are described in more detail in the online supplementary material. The parameters used and the associated references can be found in Appendix A.

The actual Virtual $\mathrm{N}$ Factors were calculated by dividing the total $\mathrm{N}$ loss by the total available $\mathrm{N}$ to find how much $\mathrm{N}_{\mathrm{r}}$ is lost to the environment per unit of $\mathrm{N}$ consumption (Table 2).

These Virtual N Factors were calculated for industrial food production facilities that are common in developed countries. Other types of food production systems (e.g., grass-fed beef) will have 


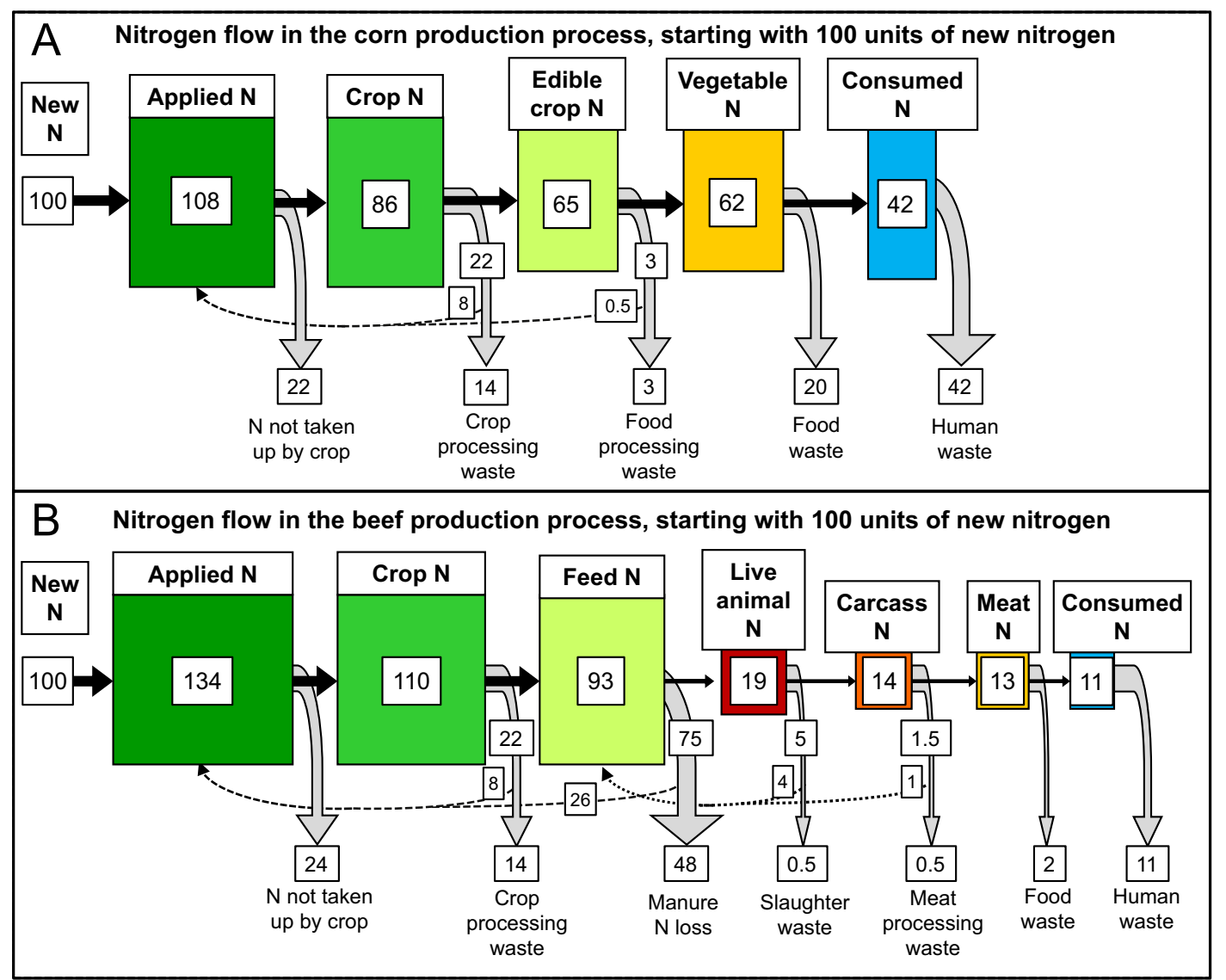

Fig. 3. $\mathrm{N}_{\mathrm{r}}$ flow in the corn and beef production processes. This explains the process used to calculate (A) $\mathrm{N}_{\mathrm{r}}$ flow in the corn production process, starting with 100 units of new $\mathrm{N}_{\mathrm{r}}$; and (B) $\mathrm{N}_{\mathrm{r}}$ flow in the beef production process, starting with 100 units of new nitrogen. Notes: (1) The colored boxes show the available $N_{r}$ at each stage of the food production process, with their areas reflecting the magnitude of $\mathrm{N}_{\mathrm{r}}$; (2) The black arrows show the $\mathrm{N}_{\mathrm{r}}$ that makes it to the next stage; (3) The start of the gray arrows is the total $\mathrm{N}_{\mathrm{r}}$ wasted, and the end of the gray arrows is the $\mathrm{N}_{\mathrm{r}}$ lost to the environment; (4) The dotted arrows show the $N_{r}$ recycled, which is subtracted from the $N_{r}$ wasted to find the $N_{r}$ lost to the environment; and (5) The diagrams show the summation of multiple iterations of the calculations; the iterations determine how recycled $\mathrm{N}_{\mathrm{r}}$ is distributed throughout the system.

Table 2

Virtual N Factors.

\begin{tabular}{lc}
\hline Food category & Virtual N Factor \\
\hline Animal products & \\
Poultry & 3.4 \\
Pigmeat & 4.7 \\
Beef & 8.5 \\
Fish and seafood & 3.0 \\
Milk & 5.7 \\
Vegetable products & \\
Vegetables & 10.6 \\
Starchy roots & 1.5 \\
Legumes & 0.7 \\
Grains & 1.4 \\
\hline
\end{tabular}

different values (Cassman 2002; Oenema et al., 2009). Even within the industrial food production system, the values in Table 2 have some variability. We estimate that the variability of the animal protein values is larger than the vegetable protein values (i.e., $40 \%$ vs. $20 \%$ ), but that the relative ranking of the values is reasonably constant. 
Using this model, the $\mathrm{N}$ footprint for each food category was then found by summing the $\mathrm{N}_{\mathrm{r}}$ in the consumed food, plus the Virtual $\mathrm{N}$ lost to the environment during the food production process. The total average per capita food $\mathrm{N}$ footprint in a country was found by summing the $\mathrm{N}$ footprint of all the food categories (Fig. 2).

Questions in the N-Calculator are asked in terms of portion sizes and the number of times per week an individual consumes a portion of food to determine the total food consumption by weight each year. Average portion sizes were calculated for each of the food categories for each country (see the online supplementary material for more information). These portion sizes were based on multiple data sources and aim to describe how much of a food type is typically consumed at a time (United States Department of Agriculture, 2002; Federatie Nederlandse Levensmiddelen Industrie, 2007). For our purposes, portion sizes generally differ from the accepted serving sizes because people generally consume more than a serving size at a time (United States Department of Agriculture, 2002). For example, although the serving size of bread is typically one slice, we use a portion size of two slices of bread since individuals typically consume two slices of bread in a sitting.

To calculate an individual's $\mathrm{N}$ footprint, the average in a country is scaled based on an individual's answers to the questions about food consumption in terms of portion sizes (Fig. 2C and D).

\subsection{Energy nitrogen footprint}

Energy consumption, the other major part of a nitrogen footprint, is related to the burning of fossil fuels and the resulting $\mathrm{NO}_{x}$ emissions. It is comprised of three different sectors: housing (e.g. cooking, heating, cooling), transportation (e.g. car, plane, public transport) and goods and services (the energy used to provide these goods and services). Estimates of the food nitrogen footprint resulting from onfarm energy usage, transportation, and catering services were calculated as part of this analysis, and these values were added in to the food production nitrogen footprint. This section describes the methodology to calculate the average per capita energy nitrogen footprint in a country (Fig. 4).

The calculation of the energy $\mathrm{N}$ footprint is a combination of two approaches: bottom-up and topdown. The bottom-up approach is the combination of activity data (e.g. kilometers driven in a car) and an emission factor (e.g. amount of $\mathrm{NO}_{x}$ emitted per kilometer driven) and is used to estimate the $\mathrm{N}$ footprint of consumption activities for which accurate emission factors are known, such as the use of electricity, burning natural gas, driving, flying, and riding public transit. The average activity data are collected for a country (Fig. 4C), and an individual's energy consumption is determined by asking questions about personal energy usage (Table 1; Fig. 4B). By multiplying the activity data with the appropriate emission factor, the total emission of that activity can be obtained (Fig. 4A). The information required for this approach originates from various sources, using different methodologies and definitions for collecting this information. Therefore, special attention has to be paid to the comparability of the data so that additional uncertainties caused by possible differences are prevented. Table 3 lists the activities accounted for using this bottom-up approach, and the data sources utilized can be found in Appendix B.

A different approach is required, however, for the Virtual $\mathrm{N}$ energy footprint that reaches consumers through more indirect means. For example, the emission factors described above can be used to estimate the amount of $\mathrm{N}_{\mathrm{r}}$ emitted to the atmosphere as a result of driving a certain distance, but they do not account for the fuel used in the production of the car itself. The top-down approach provides a method for accounting for this additional Virtual $\mathrm{N}$ energy footprint for those consumption activities that are not covered by the emission factors in Table 3. The top-down approach first calculates the total energy $\mathrm{N}$ footprint for an average resident of a nation using aggregated national statistics. A calculation of the bottom-up energy $\mathrm{N}$ footprint for the average resident is then completed, and the difference between these two calculations represents the "missing" energy $\mathrm{N}$ footprint that is not captured through the emission factor approach (Fig. 4D). This national average missing energy footprint is not scaled when the calculator does not ask related questions about personal consumption. The two portions of this top-down Virtual N energy footprint that are scaled are: (1) the food energy portion, scaled by personal food consumption, and (2) the goods and services sector, scaled by how the consumer rates his or her general level of resource consumption. 


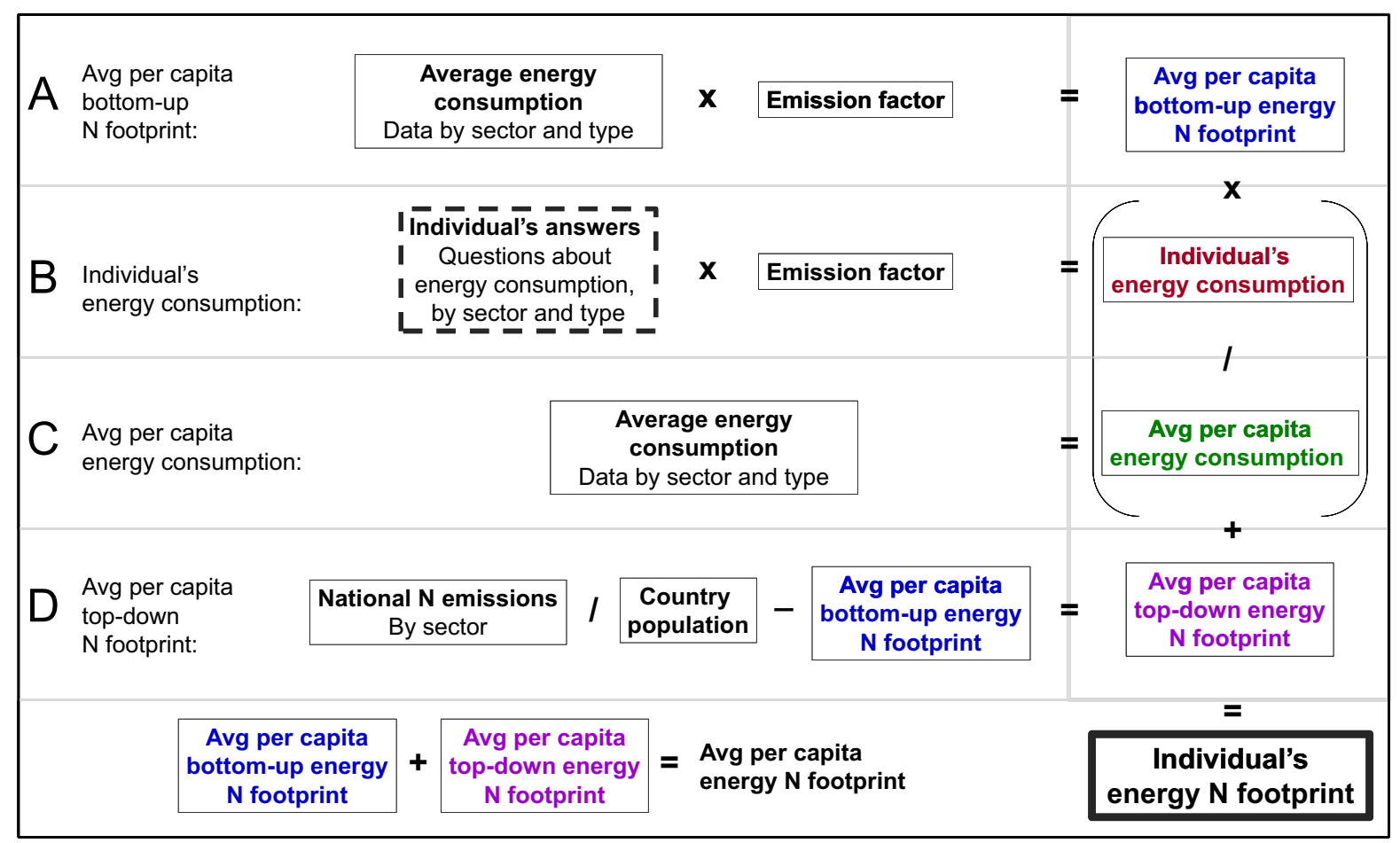

Fig. 4. Calculation schematic for the nitrogen footprint for energy. This figure explains the calculation of: (A) the average per capita bottom-up energy $\mathrm{N}$ footprint, (B) an individual's energy consumption, (C) the average per capita energy consumption, and (D) the average per capita top-down energy footprint. It is then shown how all of this information is used to find both a total average per capita energy $\mathrm{N}$ footprint and an individual's total energy $\mathrm{N}$ footprint. Notes: (1) This figure assumes the required scaling to estimate an annual $\mathrm{N}$ footprint; (2) This figure describes calculations by resource type, but assumes the summation of all resources to find the total energy $\mathrm{N}$ footprint; (3) The only input required by an individual is the dashed box; and (4) Two parts of the average per capita top-down $\mathrm{N}$ footprint $(D)$ are scaled: (i) food energy, scaled by individual food consumption, and (ii) the goods and services sector, scaled with a question about personal spending. This is not represented in the figure.

Table 3

Factors accounted for in energy $\mathrm{N}$ footprint, using bottom up approach.

\begin{tabular}{ll}
\hline Component & Data required for calculation \\
\hline Housing & Electricity used and average emission factor \\
Electricity & Natural gas used and average emission factor \\
Natural gas & \\
Transportation & Hours/distance flown on a plane and a passenger emission factor \\
Plane & Distance traveled on public transit and a passenger emission factor \\
Public transit & Distance traveled in a personal car and average emission factor \\
Personal car & \\
\hline
\end{tabular}

The top-down energy $\mathrm{N}$ footprint was calculated through an environmentally extended input-output analysis, a procedure that was developed in the mid-20th century and is today widely used in the footprint and sustainable consumption and production literature (Bicknell et al., 1997; Miller and Blair, 2009; Wiedmann et al., 2006). This analysis only includes the $\mathrm{N}_{\mathrm{r}}$ emissions related to consumption in a country that also occur within that country, meaning imported energy $\mathrm{N}_{\mathrm{r}}$ is not included.

Economic input-output tables for each nation, showing the flows of money between sectors in the economy, were collected from the Organization for Economic Cooperation and Development (OECD) input-output database (Organization for Economic Cooperation and Development, 2011). Direct sector-level emissions of nitrogen were then gathered from the Environmental Protection Agency for the US (United States Environmental Protection Agency, 2005) and from the European Environment Agency's National Emissions to LRTAP Convention dataset for the Netherlands (European Environment Agency, 2005). 
The nation-level total emissions of nitrogen were then allocated to the economic sectors responsible for the initial, direct emission into the environment (e.g. emissions from the combustion of fossil fuels to generate electricity were allocated to the electricity sector, emissions from the burning of fuel in mining equipment were allocated to the mining sector, etc.) to create a direct intensity vector, with units of direct $\mathrm{N}_{\mathrm{r}}$ emissions per dollar output of each sector.

The direct intensity vector was then multiplied by a Leontief inverse matrix derived from the input-output table to calculate the total intensity vector, with units of total $\mathrm{N}_{\mathrm{r}}$ emissions throughout the economy per dollar output of each sector (Miller and Blair, 2009). The total intensity vector represents the total upstream $\mathrm{N}_{\mathrm{r}}$ emissions that are needed for a sector to produce one dollar of output. For example, the insurance sector may have little to no direct emissions of nitrogen (a direct $\mathrm{N}$ intensity of zero), but through its purchases from other sectors such as the electricity sector, the service it provides to end users carries an embodied $\mathrm{N}$ footprint (a positive total $\mathrm{N}$ intensity). The total intensity vector is then multiplied by the household final demand vector to calculate the total household energy $\mathrm{N}$ footprint from each sector. Finally, a table produced for the United Kingdom (United Kingdom Office of National Statistics, 2010) was used to relate the output of individual sectors to personal consumption categories given by the UN Classifications Registry COICOP (Classification of Individual Consumption According to Purpose) (UN Statistics Division, 2011). While these OECD and input-output tables and COICOP tables are widely used, they have the shortcoming of aggregating all economic activity into only 48 and 41 sectors or categories, respectively.

In processing the data on direct $\mathrm{N}_{\mathrm{r}}$ emissions, we accounted for emissions of both $\mathrm{NH}_{3}$ and $\mathrm{NO}_{x}$ assuming that all $\mathrm{NO}_{x}$ is released in the form of $\mathrm{NO}_{2}$. Neither of our data sets included emissions of $\mathrm{N}_{2} \mathrm{O}$. Some minor contributors to emissions in the EPA data that were difficult to allocate to sectors (e.g. fires, fugitive emissions, accidents/catastrophes) that amount to less than $1 \%$ of total US nitrogen emissions were ignored. Approximately $14 \%$ of the total $\mathrm{N}$ emissions could not be allocated to an individual sector for the Netherlands due to a lack of resolution in the LRTAP data.

\section{Results}

$\mathrm{N}$-Calculators have been completed with data for the United States and the Netherlands. The $\mathrm{N}$-Calculator found that the average per capita $\mathrm{N}$ footprint in the United States is $41 \mathrm{~kg} \mathrm{~N} / \mathrm{yr}$ and in the Netherlands is $25 \mathrm{~kg} \mathrm{~N} / \mathrm{yr}$ (Fig. 5). For the per capita US footprint, food production accounts for $30 \mathrm{~kg} \mathrm{~N} / \mathrm{yr}$,

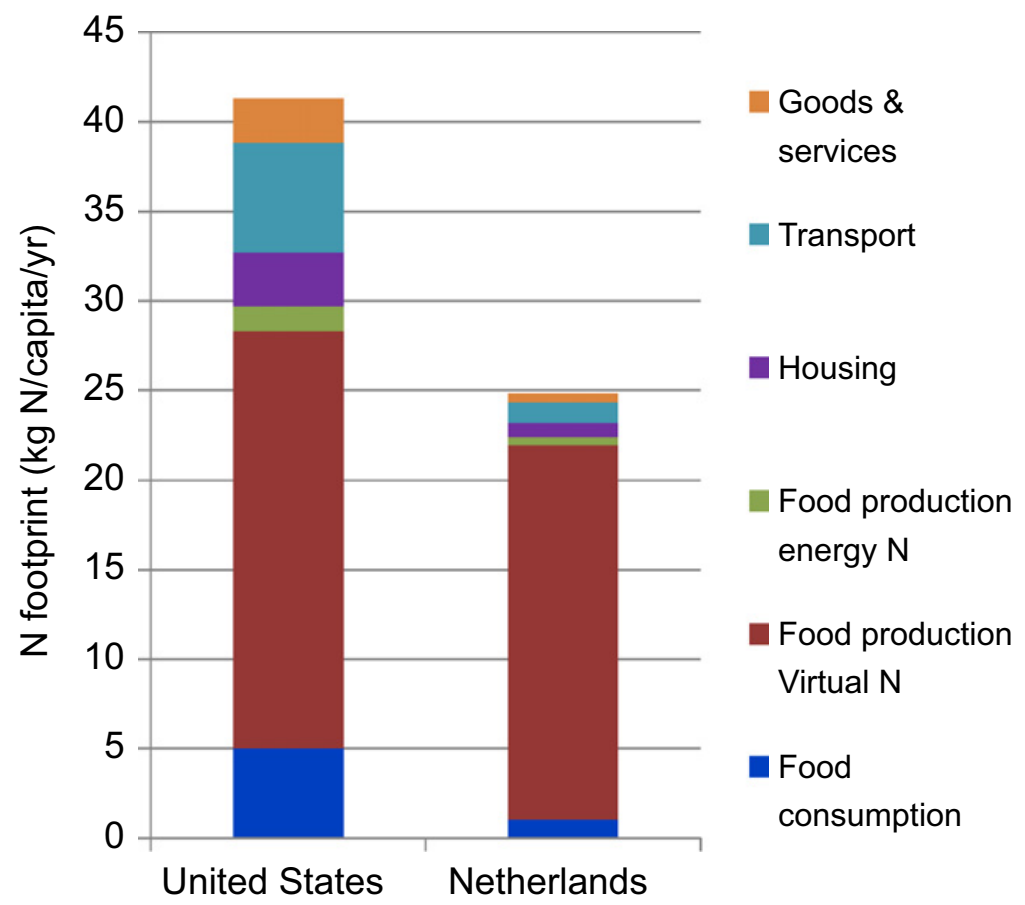

Fig. 5. Comparison of United States and Netherlands per capita $\mathrm{N}$ footprints. 
of which $25 \mathrm{~kg} \mathrm{~N} / \mathrm{yr}$ is lost to the environment prior to food consumption (e.g. during food production), and $5 \mathrm{~kg} \mathrm{~N} / \mathrm{yr}$ is lost to the environment after food consumption (e.g. as human waste). For the per capita Netherlands footprint, food production accounts for $22 \mathrm{~kg} \mathrm{~N} / \mathrm{yr}$, of which $21 \mathrm{~kg} \mathrm{~N} / \mathrm{yr}$ is lost to the environment prior to food consumption, and $1 \mathrm{~kg} \mathrm{~N} / \mathrm{yr}$ is lost to the environment after food consumption. Individuals in the Netherlands consume an average of $5 \mathrm{~kg} \mathrm{~N} / \mathrm{yr}$, but the widespread use of advanced sewage treatment converts most of this reactive nitrogen into a nonreactive form. The US energy footprint totals $12 \mathrm{~kg} \mathrm{~N} / \mathrm{capita} / \mathrm{yr}$. The energy $\mathrm{N}$ footprint is made up of the housing, transportation, and goods and services footprints, which are 3,6, and $3 \mathrm{~kg} \mathrm{~N} /$ capita/yr, respectively. The Netherlands energy footprint totals $2 \mathrm{~kg} \mathrm{~N} /$ capita/yr. The NL energy $\mathrm{N}$ footprint is made up of the housing, transportation, and goods and services footprints, which are 1,1 , and $0.5 \mathrm{~kg} \mathrm{~N} /$ capita/yr, respectively. Note that the sum of the individual parts does not necessarily equal the total due to rounding. The US and Netherlands per capita $\mathrm{N}$ footprints are compared, both as a graph (Fig. 5) and in tables (Appendix C). The top-down energy N footprint data are also available in the online supplementary material.

The differences between the US and Netherlands $\mathrm{N}$ footprints are clearly reflected in the graph and the tables. By far the largest proportion of the Netherlands $\mathrm{N}$ footprint is related to food production Virtual N. Although this is also the case for the US, other sectors in the US also contribute to a substantial amount of the $\mathrm{N}$ footprint.

\section{Discussion}

\subsection{Average per capita country nitrogen footprints}

The substantial difference between the US ( $41 \mathrm{~kg} \mathrm{~N} / \mathrm{capita} / \mathrm{yr}$ ) and Netherlands ( $25 \mathrm{~kg} \mathrm{~N} / \mathrm{capita} / \mathrm{yr}$ ) $\mathrm{N}$ footprints can be attributed to a variety of reasons across the sectors. In general, both the consumption of resources and the production losses are lower in the Netherlands than in the US.

\subsubsection{Food sector}

The amount and type of $\mathrm{N}$ consumed in each country determines the total $\mathrm{N}$ footprint. $\mathrm{N}$ consumption in the US is $5.2 \mathrm{~kg} \mathrm{~N} /$ capita/yr, and it is $4.6 \mathrm{~kg} \mathrm{~N} /$ capita/yr in the Netherlands. In the animal protein categories, the food choices in the Netherlands lead to a lower food production $\mathrm{N}$ footprint, per unit of $\mathrm{N}$ consumption. The main contributor to animal $\mathrm{N}$ consumption in the US is meat, whereas most of the $\mathrm{N}$ consumed in the Netherlands is from dairy, eggs, and fish. However, vegetable products that are less $\mathrm{N}$-efficient are consumed in the Netherlands in comparison to the $\mathrm{US}$, causing the Netherlands vegetable production $\mathrm{N}$ footprint to be larger, per unit of $\mathrm{N}$ consumption. Although these food choices are important, the main driver in reducing the food production $\mathrm{N}$ footprint in the Netherlands is the lower $\mathrm{N}$ consumption.

The Netherlands $\mathrm{N}$ footprint is also lower because advanced sewage treatment with nutrient removal technology is utilized throughout most of the country. Using this technology removes about $78 \%$ of a food consumption $\mathrm{N}$ footprint in the Netherlands (Unie van Waterschappen, 2006), or a reduction of about $3.6 \mathrm{~kg} \mathrm{~N} / \mathrm{capita} / \mathrm{yr}$. In the US, only about $5 \%$ of human waste is treated with advanced sewage treatment with nitrogen removal technology (Robert Bastian, US EPA, personal communication). It is important to note that advanced sewage treatment does not necessarily denitrify most of the reactive nitrogen in the human waste. There are many other forms of advanced sewage treatment that treat the waste in a different way but do not reduce an $\mathrm{N}$ footprint.

Although advanced sewage treatment with nutrient removal technology reduces an $\mathrm{N}$ footprint and $\mathrm{N}_{\mathrm{r}}$ losses to the environment, it could be a missed opportunity. The production process of synthetic fertilizer is energy-intensive. Recycling and reusing human waste as a fertilizer and a resource would reduce the amount of synthetic fertilizer that needs to be produced.

\subsubsection{Energy sector}

The US energy $\mathrm{N}$ footprint (12 kg N/capita/yr) was also larger than the Netherlands energy $\mathrm{N}$ footprint ( $2 \mathrm{~kg} \mathrm{~N} / \mathrm{capita} / \mathrm{yr}$ ). The difference is due to both consumption habits and energy use efficiencies. 
The biggest difference can be found in the transport sector and especially the personal car category. On average, Americans drive about $400 \mathrm{~km} /$ week, whereas the Dutch only drive about $170 \mathrm{~km} /$ week. The average public transit distance traveled in the Netherlands is greater than that in the US, but the emission factor for public transit is smaller so it has a limited impact on an $\mathrm{N}$ footprint. With the exception of public transit, all aspects of energy consumption in the US are larger. Emission factors in the US are also generally larger due to less efficient burning of fossil fuels. Both of these factors cause the US energy $\mathrm{N}$ footprint to be significantly larger than the Netherlands energy $\mathrm{N}$ footprint.

However, the Netherlands energy $\mathrm{N}$ footprint may be underestimated for two reasons. First, $14 \%$ of the direct sector emissions in the top-down energy $\mathrm{N}$ footprint could not be allocated and were not included in the footprint. Second, the imports coming into a country and their associated production and transport $\mathrm{N}_{\mathrm{r}}$ losses are not accounted for using the current top-down energy $\mathrm{N}$ footprint analysis. If the Netherlands imports a significant amount of its goods, then its energy $\mathrm{N}$ footprint would increase with the inclusion of imported $\mathrm{N}_{\mathrm{r}}$.

\subsubsection{Significance of Virtual N Factors}

There is a large variation in the Virtual N Factors, which range from 0.7 to $10.6 \mathrm{~kg} \mathrm{~N}$ released to the environment per $\mathrm{kg} \mathrm{N}$ consumed (Table 2). There is also a wide variation in their environmental consequences, which are determined by the way in which the $\mathrm{N}_{\mathrm{r}}$ is lost: to the air (as $\mathrm{NH}_{3}, \mathrm{NO}_{x}$, or $\mathrm{N}_{2} \mathrm{O}$ ) or to the ground and surface water (as $\mathrm{NH}_{4}$ or $\mathrm{NO}_{3}$ ). Depending on the loss route and form, the Virtual $\mathrm{N}$ will have different consequences to the environment. If the contribution of these $\mathrm{N}$ species to the different environmental effects were taken into account, the consumption of consumer products could be better ranked according to environmental consequences. This effort would require additional spatial information about the $\mathrm{N}_{\mathrm{r}}$ losses and the region of interest. Since this information extends beyond the scope of the current $\mathrm{N}$ footprint calculator, the ranking of the $\mathrm{N}$ forms and their consequences is not taken into account here. However, this important analysis will be completed and utilized in the N-Producer and N-Policy models of the final N-PRINT system.

\subsection{Top-down $N$ footprint estimate: a cross-check}

The N-Calculator estimates the nitrogen footprint of countries by using data on total food consumption from the FAOSTAT, Virtual N Factors associated with food consumption, and with fossil fuel emissions associated with housing, transportation, goods, and services. In this regard it is a bottom-up calculation in that it is based on consumption of food and energy. There is another independent method that calculates the same thing. This method is a top-down analysis, as it starts with how much $\mathrm{N}_{\mathrm{r}}$ is introduced into the country from food and energy production. More specifically, the $\mathrm{N}_{\mathrm{r}}$ sources are (1) $\mathrm{NO}_{x}$ formed during fossil fuel combustion, (2) $\mathrm{N}_{\mathrm{r}}$ fixed by cultivation-induced BNF, and (3) fertilizer applied to grow food. It is important to note that this top-down analysis is different from the top-down energy $\mathrm{N}$ footprint described in Section 2.3.

Since this is an independent analysis, it can be used to cross-check the value from the bottom-up calculation in $\mathrm{N}$-Calculator. The comparison of this top-down to the $\mathrm{N}$-Calculator bottom-up approach works best for those countries where food production is within the countries' borders (i.e., limited food imports) because all of the production-related $\mathrm{N}_{\mathrm{r}}$ losses occur in the consuming country.

As an example, we did this for the US (where $95 \%$ of the food consumed is produced within the country) using a recent analysis of the national nitrogen budget for 2002 (United States Environmental Protection Agency, 2011).

(1) For fossil fuel combustion, $5.7 \mathrm{Tg} \mathrm{N} / \mathrm{yr}$ was introduced into the US atmosphere. Expressed on a per-capita basis, it is $19 \mathrm{~kg} \mathrm{~N} / \mathrm{yr}$.

(2) For food production, C-BNF and fertilizer application introduces $7.7 \mathrm{Tg} \mathrm{N} / \mathrm{yr}$ and $9.8 \mathrm{Tg} \mathrm{N} / \mathrm{yr}$, respectively, into agroecosystems. Expressed on a per-capita basis, it is $58 \mathrm{~kg} \mathrm{~N} / \mathrm{yr}$. 
These can be compared to the energy and food components of N-Calculator. For the former, the total for housing, transportation and goods and services (whose contribution to the $\mathrm{N}$ footprint is measured as $\mathrm{NO}_{x}$ emissions from fossil fuel combustion) is $12 \mathrm{~kg} \mathrm{~N} /$ capita/yr, compared to the topdown estimate of $19 \mathrm{~kg} \mathrm{~N} /$ capita/yr.

For food production, the average footprint from the bottom-up is $30 \mathrm{~kg} \mathrm{~N} / \mathrm{capita} / \mathrm{yr}$, compared to the top-down estimate of $58 \mathrm{~kg} \mathrm{~N} /$ capita/yr. The reason for the difference in the food calculation is because the bottom-up is consumption-based-it starts with what people consume and then works down the production stream to calculate the total $\mathrm{N}$ footprint. However, the top-down examines all the $\mathrm{N}_{\mathrm{r}}$ that is used to produce both what is consumed, and what is exported. For a correct comparison, the amount of $\mathrm{N}_{\mathrm{r}}$ that is exported and its production losses needs to be subtracted from the $58 \mathrm{~kg} /$ capita/yr. Since the amount exported is $4.1 \mathrm{Tg} \mathrm{N} / \mathrm{yr}$ ( $14 \mathrm{~kg} \mathrm{~N} /$ capita/yr), and since it is mostly grain (i.e., wheat, maize, soybeans), which has production losses of about $60 \%$ of the grain exported, the total $\mathrm{N}_{\mathrm{r}}$ associated with grain that is exported is $6.6 \mathrm{Tg} \mathrm{N} / \mathrm{yr}$. This leads to a corrected top-down food production value of $36 \mathrm{~kg} \mathrm{~N} /$ person/yr, which compares well with the consumption based, bottom-up analysis or $30 \mathrm{~kg} \mathrm{~N} /$ person/yr. The remainder of the difference is likely explained by the inclusion of agriculture used for non-food purposes, such as corn for ethanol, in the top-down estimate but not in the bottom-up estimate.

\subsection{Quality of the data}

Due to the nature of the $\mathrm{N}$ footprint analysis in finding averages in a country, there are uncertainties in the data. The averages used in the $\mathrm{N}$-Calculator are appropriate for a country overall, but may not be suitable for an individual's situation. For example, because the N-Calculator focuses on conventional agriculture, the $\mathrm{N}$ footprint of organic beef may not be accurately calculated. However, the tool in its current version aims to serve as an educational device that can show individuals the relative nitrogen impact of their decisions, rather than to precisely calculate the $\mathrm{N}$ footprint of specific situations.

\subsubsection{Food data}

The FAO data, which were used for food consumption estimates, are generally reliable for developed countries. The consumption data is reported by individual countries to the FAO, making the FAO dependent on the resources available in a country.

The individual parameters used to calculate the Virtual N Factors (Appendix A) ranged in level of certainty. Capturing average estimates for the food production process is difficult because much variation exists, even within a single farm. Furthermore, Virtual N Factors were only developed for the major food categories, meaning that a factor is not available for every food category. In these cases, the Virtual N Factor for the food produced most similarly was used, for example the vegetables factor was used for fruit. The Virtual $\mathrm{N}$ Factors also only describe the average industrial food production process in the US. Although very similar, the food production process in the Netherlands is different than the US. Additionally, much variation exists in the food production process within the US. As the Virtual $\mathrm{N}$ Factors describe the average, they cannot accurately calculate the $\mathrm{N}$ footprint of a food item grown using unconventional methods. The N-Calculator provides a framework for using different data from different sources.

\subsubsection{Energy data}

The energy data in the $\mathrm{N}$-Calculator describe the average situation in a country. Country averages for national $\mathrm{N}_{\mathrm{r}}$ emissions, resource consumption, and emission factors were obtained from reputable sources (Appendix B).

Although individuals using the $\mathrm{N}$-Calculator can modify the average resource consumption to fit their lifestyle, they do not have as much control over the emission factors. These average emission factors accurately describe a country overall, but may not accurately represent an individual's consumption choices. For example, the electricity emission factor assumes the average type of fuel used to produce electricity; individuals cannot select a specific energy source like nuclear power, 


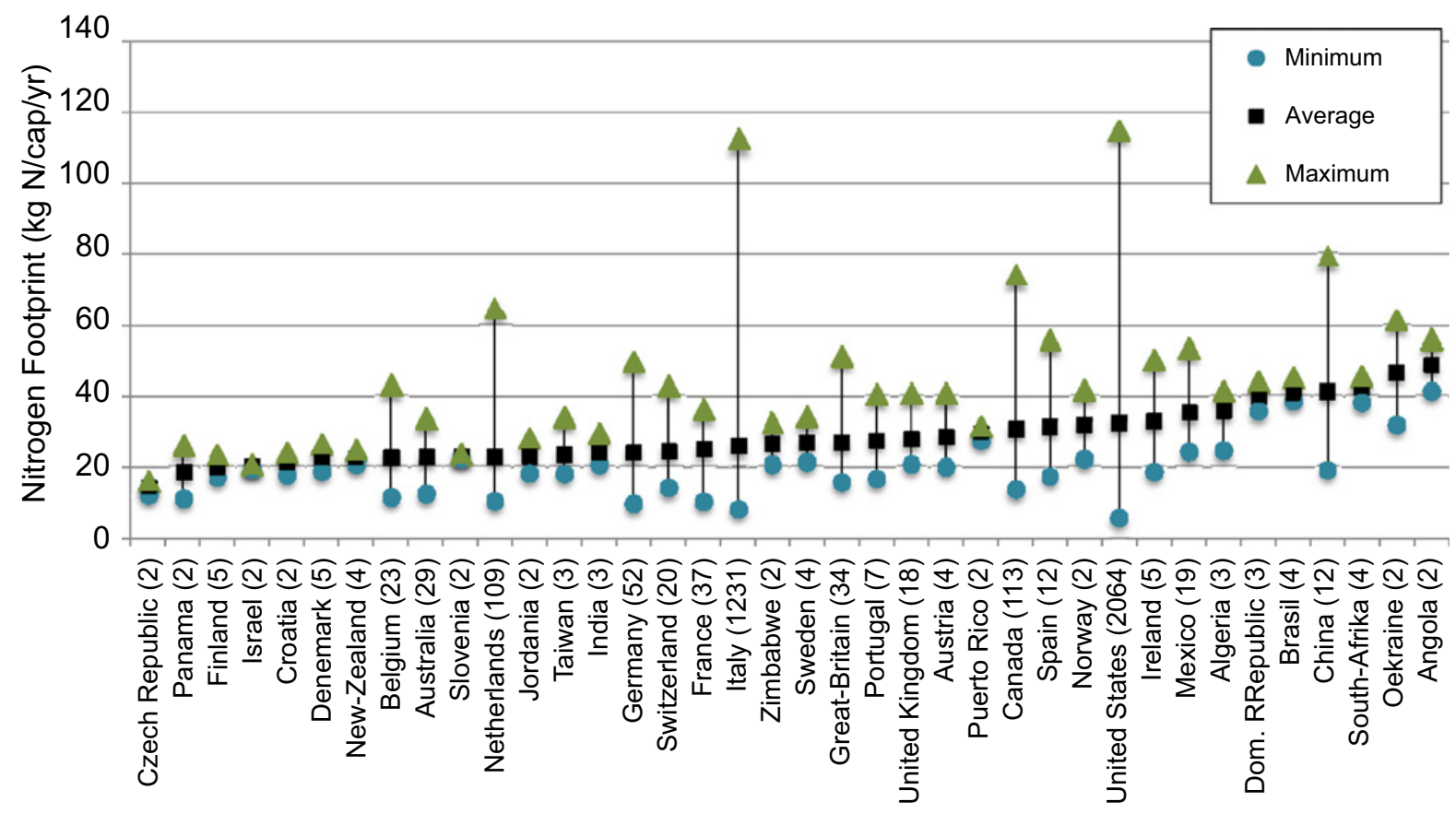

Fig. 6. Average $\mathrm{N}$ footprints of online users of the $\mathrm{N}$-Calculator. Notes: The numbers in brackets after the country names show the number of footprints calculated per country using the N-Calculator.

solar energy, or coal. However, some exceptions exist. For example, in the US, an individual can select his home state, and the $\mathrm{N}$-Calculator will then select the average for that state rather than for the country overall. Additionally, users can choose what kind of car they drive, as different cars can have varying efficiencies.

Many of the items listed above as shortcomings in both the food and energy data will be improved upon in the future. For example, the next version of the N-Calculator will account for additional food production methods and it will provide users with more options in the energy section to better represent their personal situation. However, the N-Calculator will never perfectly calculate the $\mathrm{N}$ footprint of every situation because it is an educational tool that relies on averages.

\subsection{Use of the N-Calculator to date}

The calculator was launched in February 2011 and since then it has been tested and used by over 5000 people (Fig. 6). The distribution gives an impression of the interest people have in receiving information about their personal footprint. When viewing the data, it is important to note that individuals often use the online $\mathrm{N}$-Calculator to test scenarios, meaning that the outliers are often not accurate $\mathrm{N}$ footprint estimates of individuals. Additionally, individuals from countries other than the US and the Netherlands must select one of those two countries to use the N-Calculator, possibly making their $\mathrm{N}$ footprint results unsuitable for their situation.

\section{Conclusions}

Over the past few years, several footprint approaches have been developed for water, carbon, and for the ecological effects of human consumption. Here we present the first $\mathrm{N}$ footprint calculator. The disruption of the regional to global $\mathrm{N}$ cycle and its consequences is not well known to the public and to policymakers. Furthermore, because of the complexity of the issue there is only limited knowledge about how to optimize the increasing need for food and energy while limiting the effects of $\mathrm{N}_{\mathrm{r}}$ in the environment. Such effects include the impacts on ecosystem services (including food production, biodiversity, and other services), the effects on human health (air and water quality) and the impacts on climate change. 
Here we present the N-Calculator as a first step in the development of a set of tools to help policymakers, producers, and consumers. The $\mathrm{N}$-Calculator is a personal $\mathrm{N}$ footprint calculator that provides an estimate for a person in a certain country of the $\mathrm{N}_{\mathrm{r}}$ that he or she consumes in food and uses through fossil fuels and the $\mathrm{N}_{\mathrm{r}}$ that was used in production (and lost to the environment) to produce the food, energy, and products. This tool is based on the general footprint data for the country, changed by the personal consumption patterns obtained by an inquiry on the web (www.N-PRINT.org). The calculator uses the best available country specific data on emission factors, resource consumption, etc. We selected the best scientific knowledge to provide the parameters and factors. The range of some of the parameters might be big and uncertainty can be large, but since this is a relative indicator and used as such, this does not make a difference for the main purpose of the calculator, which is to help consumers understand the issues and find ways to reduce their $\mathrm{N}$ footprint.

The overarching message from the $\mathrm{N}$-Calculator is that our lifestyle choices, and especially our food consumption, have major impacts on the $\mathrm{N}_{\mathrm{r}}$ losses to the environment. A reduction in meat consumption is a very efficient way of reducing an $\mathrm{N}$ footprint. Furthermore, the type of meat and the way it is produced makes a difference. Energy consumption is generally very high in developed countries, and limiting our resource consumption would positively impact our energy $\mathrm{N}$ footprints. Communicating these messages to all of the stakeholders (the public, policymakers, and governments) through tools like the $\mathrm{N}$-Calculator will help reduce $\mathrm{N}_{\mathrm{r}}$ losses to the environment.

The next steps in the development of the N-PRINT tool will be to link the $\mathrm{N}_{\mathrm{r}}$ losses to effects. For this we will need to estimate the losses to the environment in terms of emissions to the air (ammonia and $\mathrm{NO}_{x}$ ) and the run-off and leaching to groundwater and rivers (nitrate). Additionally, we will have to link this to the cascading effects in different regions to the global scale to provide quantitative estimates of the relationship between the Virtual $\mathrm{N}$ and the environmental impacts. Finally, we will have to collect data, parameters, and factors to enable footprints for different regions/countries in the world. The basis for the N-Producer and N-Policy models is laid out with the $\mathrm{N}$-Calculator. However, several further developments are needed in this direction, which will be addressed in future papers.

\section{Role of the funding source}

This study was supported with funding from a variety of sources. We appreciate the assistance we have received from the Agouron Institute, the Energy Research Center of the Netherlands, the Tyler Foundation, the United States Environmental Protection Agency, the Netherlands Ministry of Infrastructure and the Environment, and the University of Virginia. These sponsors have not played a role in the study design, the data, the report, or the decision to submit a paper for publication.

\section{Acknowledgments}

This paper is a contribution to the International Nitrogen Initiative. A topic of this breadth required intellectual support from many individuals, and we are very thankful to the following for their important input: Dale Allen, Robert Bastian, Marshall Burke, Russell Dickerson, Otto Doering, Rick Haeuber, Arjan Hensen, Brendan McLaughlin, Bill Moomaw, Harold Mooney, Carolyn Opio, Nicolas Sakoff, Kaj Sanders, Henning Steinfeld, Thomas Theis, and Penelope Whitney.

\section{Appendix A. Food production $\mathrm{N}$ footprint data and references}

This appendix lists the steps, data, and references used to calculate Virtual N Factors, which describe the $N_{r}$ lost to the environment throughout the food production process for the major food categories (Tables A1-A3). 


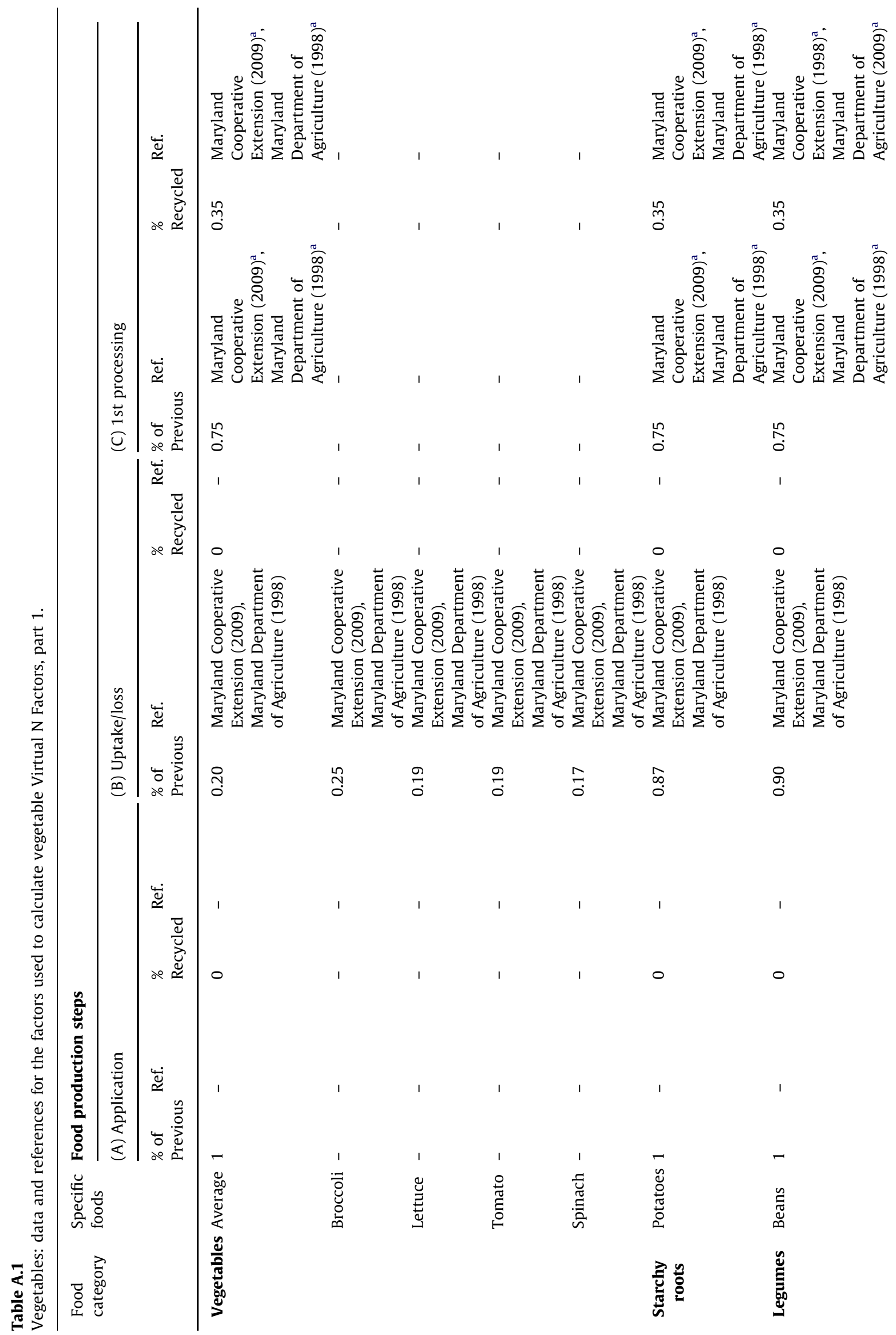




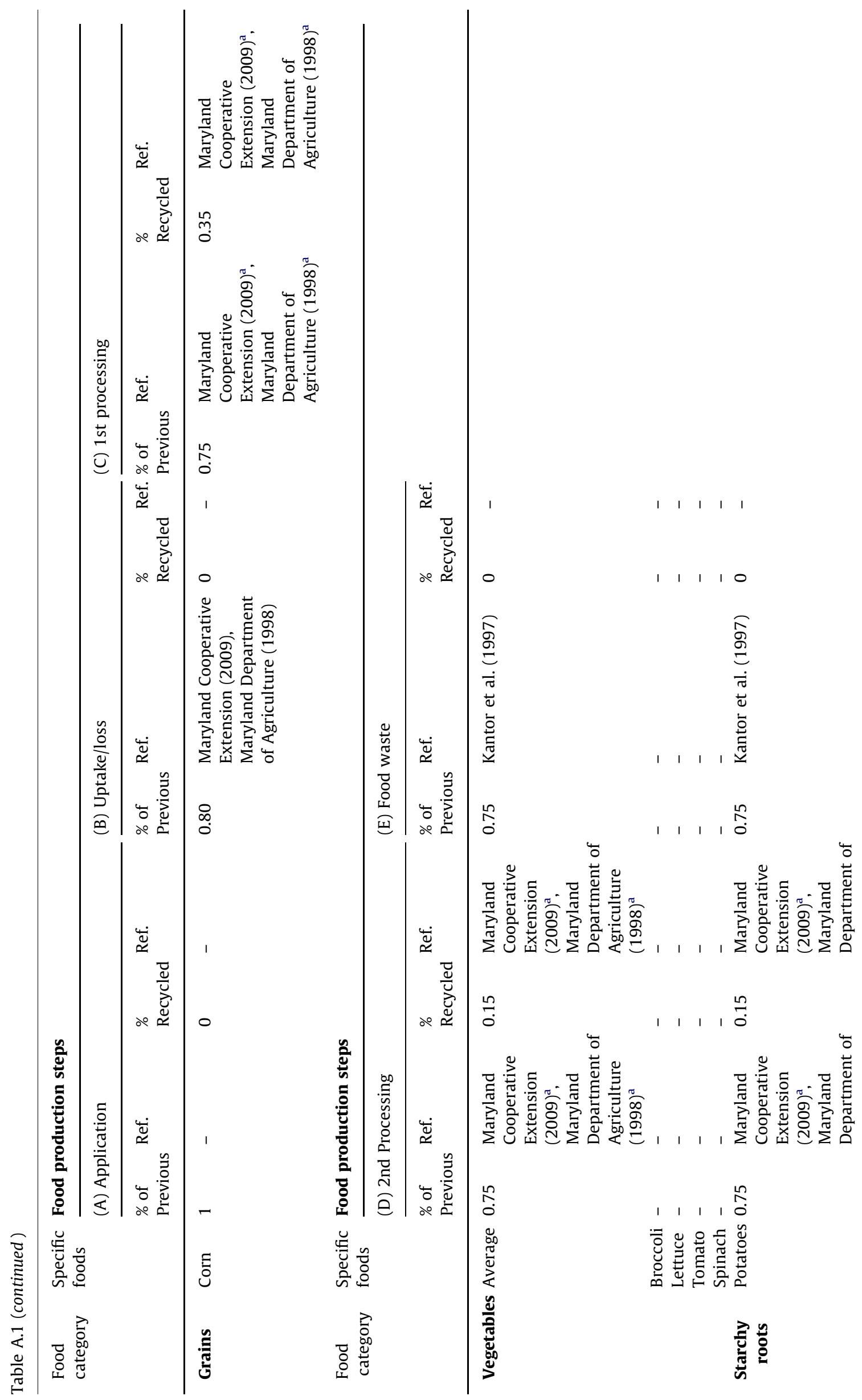




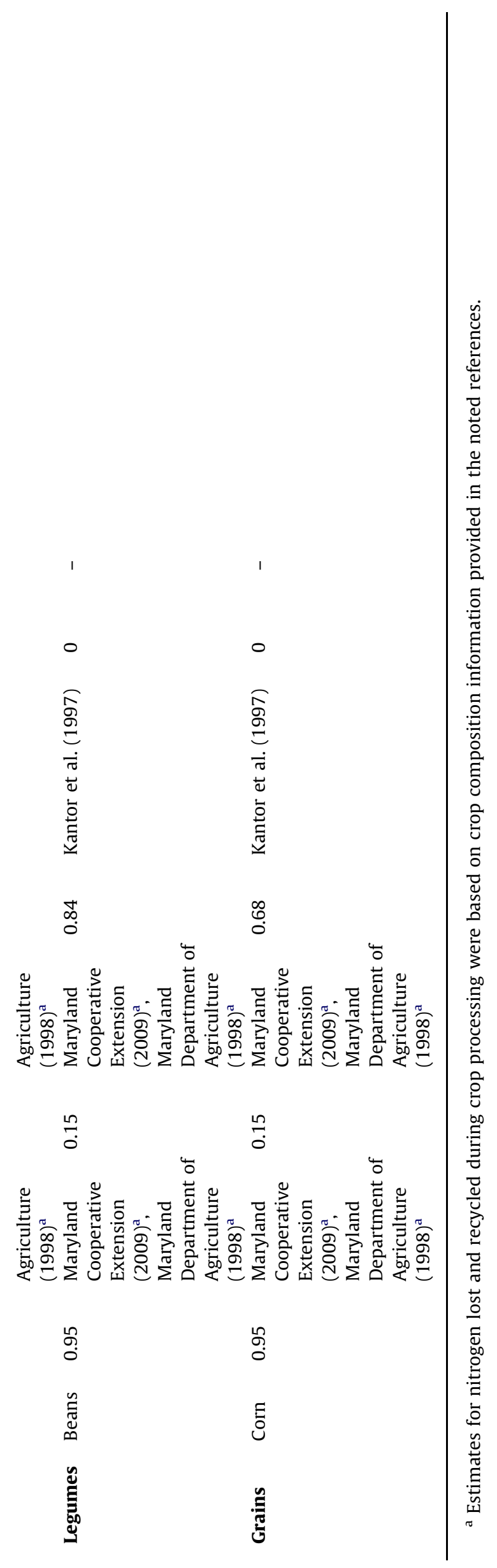




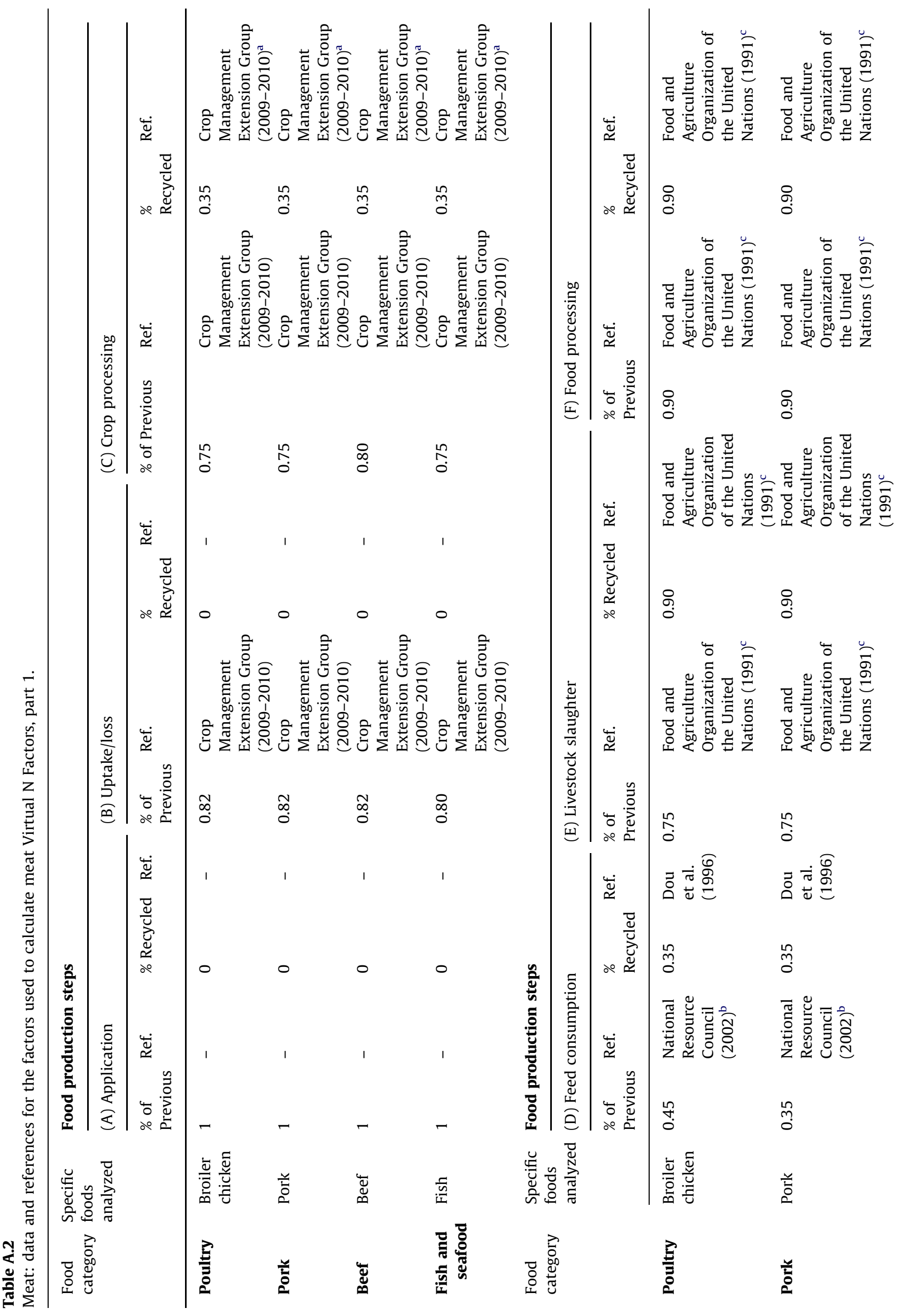




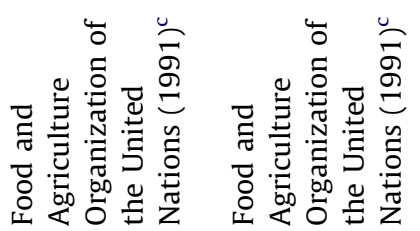

ஓ :

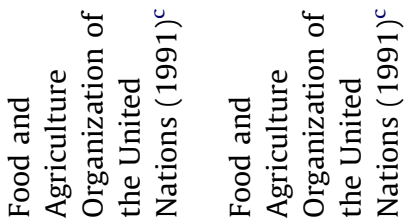

ஓ. ஃ

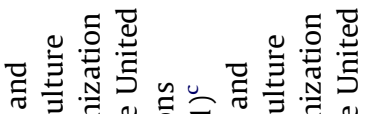

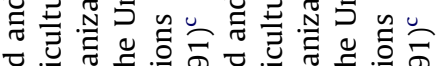

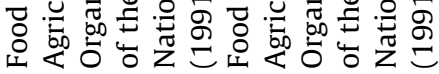

ஓ. :

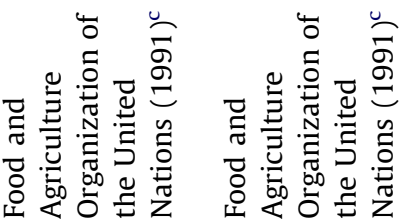

$\stackrel{\substack{n \\ \stackrel{n}{0}}}{\stackrel{n}{0}}$

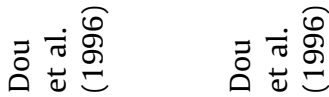

$\stackrel{n}{0} \quad \stackrel{n}{0}$

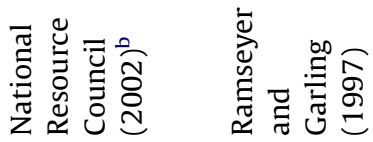

กิ

ֻ̊.

管

凹్

$\frac{5}{5}$

产

ฐँ

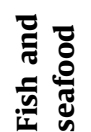

哭

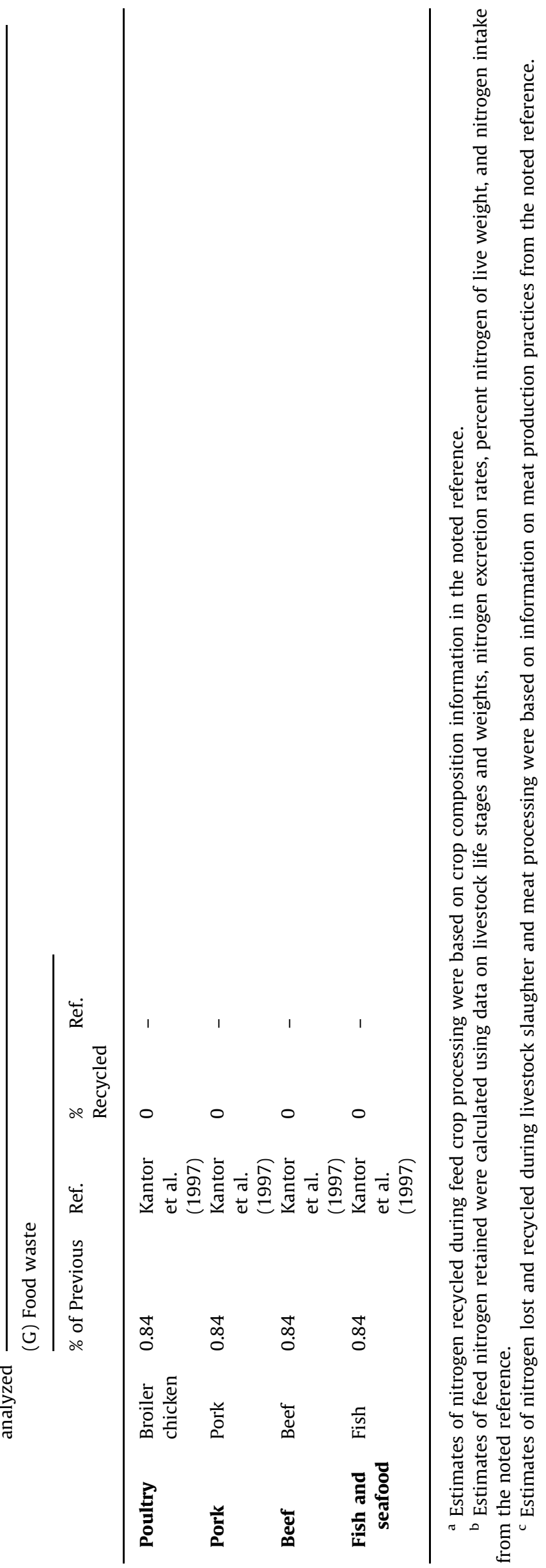




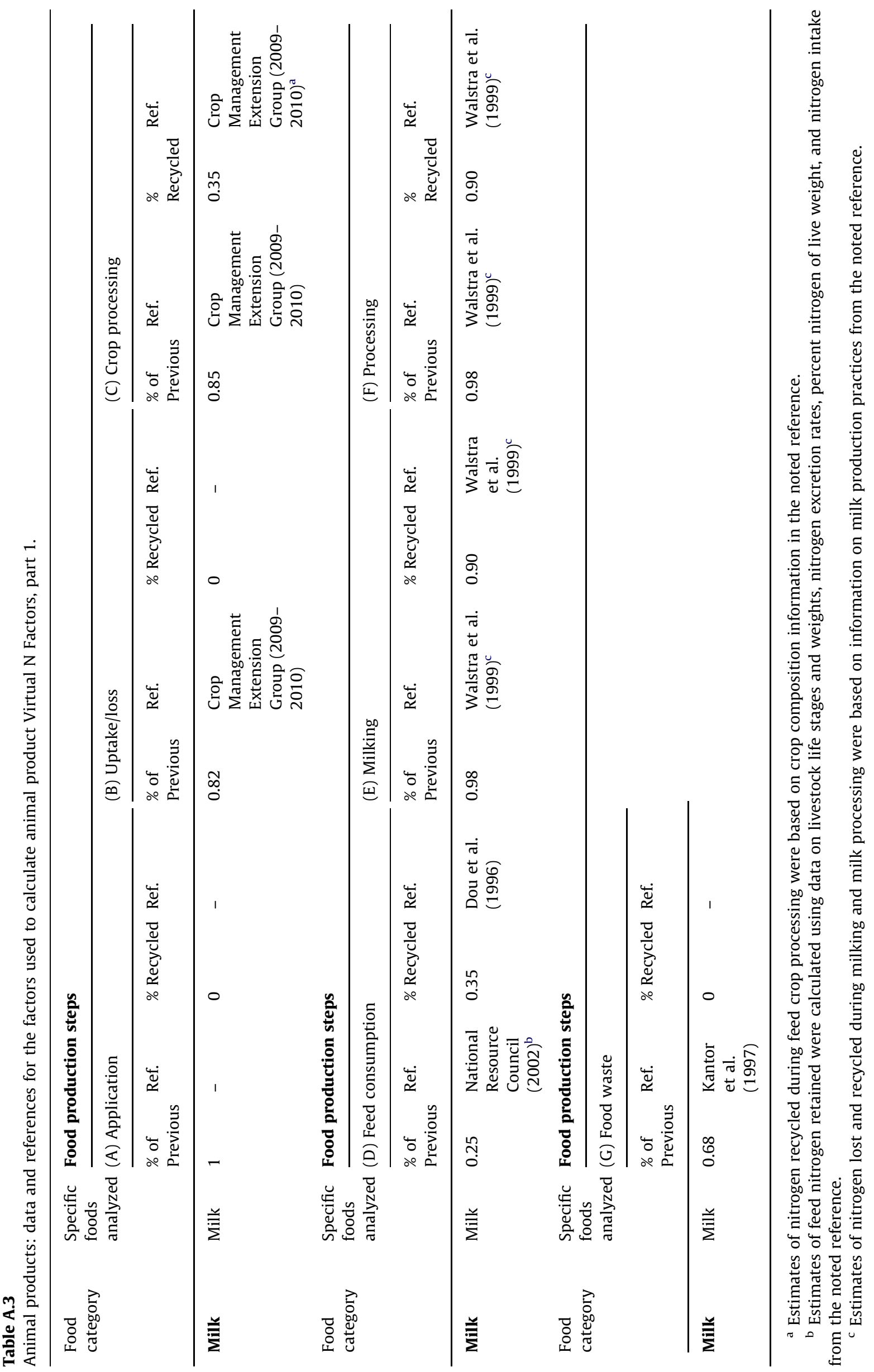


References for food Virtual N Factor calculations (Tables A1-A3)

Crop Management Extension Group, Pennsylvania State University, University Park, 2009-2010. The Penn State Agronomy Guide, 〈http://extension.psu.edu/agronomy-guide/agronomy-guide/cm $\rangle$.

Dou, Z., Kohn, R.A., Ferguson, J.D., Boston, R.C., Newbold, J.D., 1996. Managing nitrogen on dairy farms: an integrated approach I. Model description. Dairy Science 79, 2071-2080.

Food and Agriculture Organization of the United Nations, 1991. Guidelines for Slaughtering, Meat Cutting and Further Processing. Food and Agriculture Organization of the United Nations, Rome.

Kantor, L.S., Lipton, K., Manchester, A., Oliveira, V., 1997. Estimating and Addressing America's Food Losses, United States Department of Agriculture Economic Research Service: Food Review.

Maryland Cooperative Extension, 2009. Commercial Vegetable Production Recommendations in Maryland. Publication EB-236, <http://www.mdipm.umd.edu/state_resources/MD\%20VEG\%20REC\% 202009.pdf $>$.

Maryland Department of Agriculture, Agriculture in Maryland Summary, 1998. Maryland Department of Agriculture, Annapolis, Maryland.

National Resource Council, 2002. Air Emissions from Animal Feeding Operations. The National Academies Press, Washington, DC.

Ramseyer, L., Garling, D., 1997. Fish Nutrition and Aquaculture Waste Management, IllinoisIndiana Sea Grant Program, Publication CES-305.

Walstra, P., Geurts, T.J., Noomen, A., Jellema, A., van Boekel, M.A.J.S., 1999. Dairy Technology: Principles of Milk Properties and Processes. Marcel Dekker, Inc., New York, NY.

\section{Appendix B. Energy $\mathbf{N}$ footprint data and references}

This appendix lists the data and references used to calculate the bottom-up energy $\mathrm{N}$ footprint (Table B1).

References for bottom-up energy N footprint calculations (Table B1)

Allen, A., Dickerson, R., Personal Communication, January 2010.

Boeing, Commercial Airplanes. 〈http://www.boeing.com/commercial/index.html 〉, (accessed 27 July 2011).

Compendium of the Environment. 〈http://www.compendiumvoordeleefomgeving.nl $\rangle$, (accessed September 2009).

Just Live Greener, Top 5 Hybrid Cards for 2010. 〈http://www.justlivegreener.com/greener-tran sportation/115-top-5-hybrid-cars-for-2010.html $\rangle$, (accessed February 2011). 


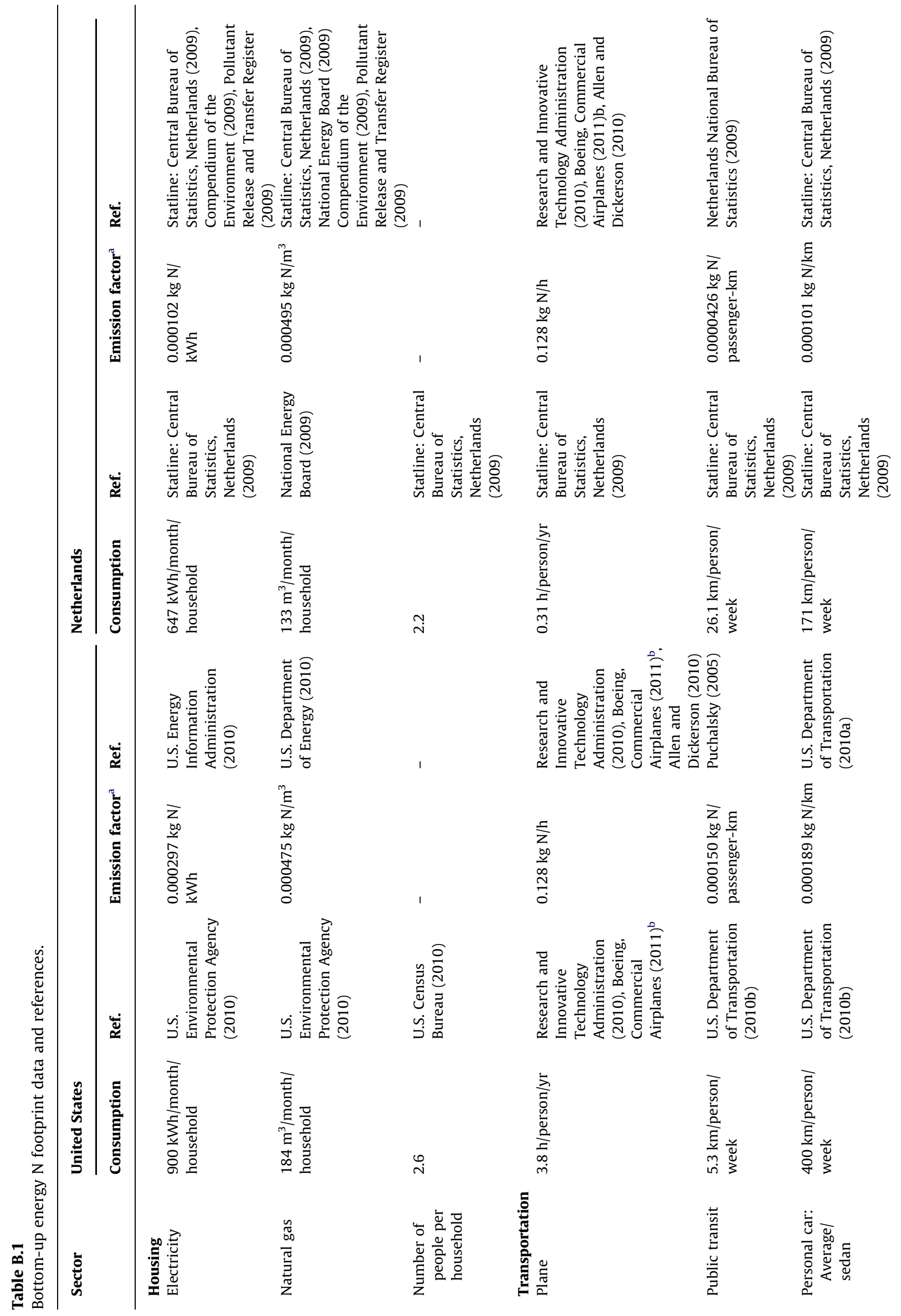




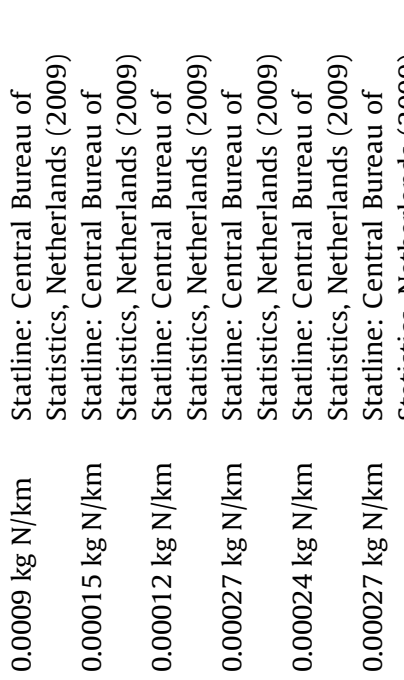

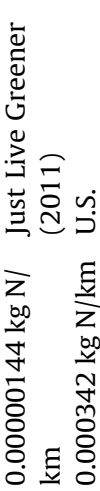

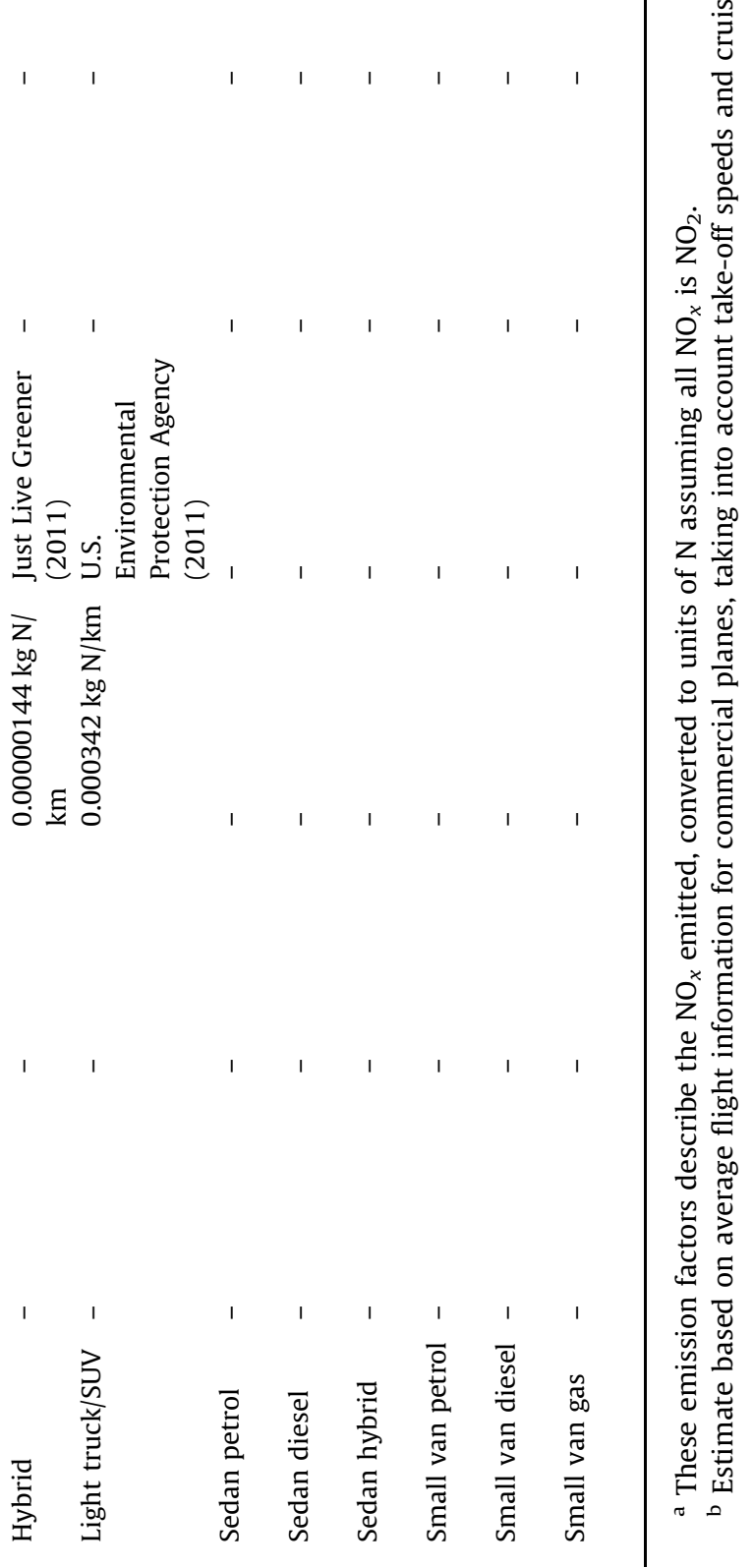


National Energy Board, Conversion Factors. 〈http://www.gadsnxl.com/downloads/moreconver sions_e.pdf $>$, (accessed September 2009).

Netherlands National Bureau of Statistics. 〈http://www.cbs.nl $\rangle$, (accessed September 2009).

Pollutant Release and Transfer Register. 〈http://www.emissieregistratie.nl $\rangle$, (accessed September 2009).

Research and Innovative Technology Administration, Table 1-37: U.S. Passenger-Miles. 〈http:// www.bts.gov/publications/national_transportation_statistics/html/table_01_37.html $\rangle$, (accessed August November 2010).

Puchalsky, C.M., 2005. Comparison of Emissions from Light Rail Transit and Bus Rapid Transit, Public Transportation Planning and Development Committee. 〈http://www.actfortransit.org/docs/ 2008JulLRTvsBRTemmissions.pdf $\rangle$, (accessed June 2010).

Statline: Central Bureau of Statistics, Netherlands. 〈http://statline.cbs.nl/statweb/ $\rangle$, (accessed September 2009).

U.S. Census Bureau, 2005-2009 American Community Survey 5-Year Estimates: Data Profile Highlights. 〈http://factfinder.census.gov/servlet/ACSSAFFFacts?_event=\&geo_id=01000US\&_geoContext= 01000US\&_street $=$ \&_county $=$ \&_cityTown $=$ \&_state $=$ \&_zip=8_lang=en\&_sse $=$ on\&ActiveGeoDiv=8_useEV= \&pctxt=fph\&pgsl=010\&_submenuId=factsheet_1\&ds_name=DEC_2000_SAFF\&_ci_nbr=null\&qr_name=nul $1 \&$ reg=\&_keyword=\&_industry= $>$, (accessed June 2010).

U.S. Department of Energy: Energy Efficiency and Renewable Energy. <http://www1.eere.energy. gov/buildings/appliance_standards/residential/pdfs/k-2.pdf $\rangle$, (accessed June 2010).

\section{Appendix C. Results of the N-Calculator}

This appendix breaks down the N-Calculator results for the US and the Netherlands into more specific categories, such as specific food types and specific categories in the housing sector (Tables C1 and C2).

Table C.1

Comparison of United States and Netherlands food N footprints.

\begin{tabular}{|c|c|c|c|c|}
\hline Sector & $\begin{array}{l}\text { Food consumption } \mathbf{N} \text {, and } \\
\text { (after sewage treatment) } \\
\text { (kg N/capita/yr) }\end{array}$ & $\begin{array}{l}\text { Food production } \\
\text { Virtual N } \\
\text { (kg N/capita/yr) }\end{array}$ & $\begin{array}{l}\text { Food production } \\
\text { energy } \mathbf{N} \\
(\mathrm{kg} \mathrm{N} / \text { capita/yr) }\end{array}$ & $\begin{array}{l}\text { Total food } \mathbf{N} \\
\text { footprint } \\
\text { (kg N/capita/yr) }\end{array}$ \\
\hline \multicolumn{5}{|l|}{ United States } \\
\hline Meat & $2.1(2.0)^{\mathrm{a}}$ & 11.2 & 0.1 & 13.3 \\
\hline Dairy/eggs/fish & $1.4(1.3)^{\mathrm{a}}$ & 7.0 & 0.3 & 8.6 \\
\hline Vegetables & $1.8(1.7)^{\mathrm{a}}$ & 5.1 & 1.0 & 7.8 \\
\hline Total & $5.2(5.0)^{\mathrm{a}}$ & 23.3 & 1.4 & 29.7 \\
\hline \multicolumn{5}{|l|}{ Netherlands } \\
\hline Meat & $1.3(0.3)^{b}$ & 6.8 & 0.0 & 7.1 \\
\hline Dairy/eggs/fish & $1.8(0.4)^{\mathrm{b}}$ & 9.3 & 0.1 & 9.8 \\
\hline Vegetables & $1.5(0.3)^{b}$ & 4.9 & 0.4 & 5.6 \\
\hline Total & $4.6(1.0)^{b}$ & 20.9 & 0.5 & 22.4 \\
\hline
\end{tabular}

a As only $5 \%$ of homes in the US have tertiary sewage treatment with nitrogen removal technology, it is assumed that the average person's waste is not treated with this technology. The calculation above in parentheses shows the average US footprint with $5 \%$ treatment.

${ }^{\mathrm{b}}$ The widespread use of advanced sewage treatment in the Netherlands leads to a $78 \%$ reduction in the Netherlands food consumption $\mathrm{N}$ footprint, which is reflected in the parentheses in the food consumption $\mathrm{N}$ column. 
Table C.2

Comparison of United States and Netherlands energy $\mathrm{N}$ footprints.

\begin{tabular}{lll}
\hline Sector & $\begin{array}{l}\text { United States } \\
\text { (kg N/capita/yr) }\end{array}$ & $\begin{array}{l}\text { Netherlands } \\
\text { (kg N/capita/yr) }\end{array}$ \\
\hline Housing & $\mathbf{3 . 0}$ & $\mathbf{0 . 8}$ \\
Electricity & 1.2 & 0.4 \\
Natural Gas & 0.4 & 0.4 \\
Other & 1.4 & 0.1 \\
Transport & $\mathbf{6 . 0}$ & $\mathbf{1 . 1}$ \\
Plane & 0.5 & 0.0 \\
Public Transit & 0.0 & 0.1 \\
Personal Car & 3.9 & 0.9 \\
Other & 1.6 & 0.1 \\
Goods and Services & $\mathbf{2 . 5}$ & $\mathbf{0 . 5}$ \\
Goods & 1.2 & 0.3 \\
Services & 1.3 & 0.2 \\
\hline
\end{tabular}

\section{Appendix D. Supporting information}

Supplementary data associated with this article can be found in the online version at doi:10.1016/ j.envdev.2011.12.005.

\section{References}

Burke, M., Oleson, K., McCullough, E., Gaskell, J., 2008. A global model tracking water, nitrogen, and land inputs and virtual transfers from industrialized meat production and trade. Environmental Modeling \& Assessment. doi:10.1007/s10666008-9149-3.

Balasubramanian, V., Alves, B., Aulakh, M., Bekunda, M., Cai, Z., Drinkwater, L., Mugendi, D., van Kessel, C., Oenema, O., 2004. Crop, environmental and management factors affecting nitrogen use efficiency. in: Mosier, A.R., Syers, J.K., Freney, J.R. (Eds.), Agriculture and the Nitrogen Cycle: Assessing the Impacts of Fertilizer Use on Food Production and the Environment. Island Press, Washington, DC, pp. 19-33.

Bicknell, K.B., Ball, R.J., Cullen, R., Bigsby, H.R., 1997. New methodology for the ecological footprint with an application to the New Zealand economy. Ecological Economics 27, 149-160.

Chesapeake Bay Foundation: Your Bay Footprint. Accessed 10 June 2011, 〈http://www.cbf.org/Page.aspx?pid=1136 $\rangle$.

Cassman, K.G., Dobermann, A., Walters, D.T., 2002. Agroecosystems, nitrogen-use efficiency, and nitrogen management. Ambio 31, 132-140.

Erisman, J.W., Galloway, J.N., Sutton, M.A., Klimont, Z., Winiwarter, W., 2008. How a century of ammonia synthesis changed the world. Nature Geoscience 1, 636-639.

European Environment Agency, 2005. National emissions reported to the Convention on Long-range Transboundary Air Pollution. Accessed 10 June 2011, 〈http://www.eea.europa.eu/data-and-maps/data/national-emissions-reported-to-theconvention-on-long-range-transboundary-air-pollution-lrtap-convention-3 $\rangle$.

Fissore, C., Baker, L.A., Hobbie, S.E., King, J.Y., McFadden, J.P., Nelson, K.C., Jakobsdottir, I., 2011. Carbon, nitrogen, and phosphorus fluxes in household ecosystems in the Minneapolis-Saint Paul, Minnesota, urban region. Ecological Applications 21, 619-639.

Food and Agriculture Organization of the United Nations Statistics. Accessed 15 June 2011, <http://faostat.fao.org/site/345/ default.aspx $>$.

Federatie Nederlandse Levensmiddelen Industrie, Guideline Implementation CIAA Voluntary Agreement Nutritional Value Labeling, 2007.

Galloway, J.N., Cowling, E.B., 2002. Reactive nitrogen and the world: 200 years of change. Ambio 31, 64-71.

Galloway, J.N., Aber, J.D., Erisman, J.W., Seitzinger, S.P., Howarth, R.W., Cowling, E.B., Cosby, B.J., 2003. The nitrogen cascade. Bioscience 53, 341-356.

Galloway, J.N., Burke, M., Bradford, E., Naylor, R.L., Falcon, W.P., Mooney, H.A., Gaskell, J., Oleson, K., McCullough, E., Steinfeld, H., 2007. International trade in meat-the tip of the pork chop. Ambio 36, 622-629.

Galloway, J.N., Townsend, A.R., Erisman, J.W., Bekunda, M., Cai, Z., Freney, J.R., Martinelli, L.A., Seitzinger, S.P., Sutton, M.A., 2008. Transformations of the nitrogen cycle: recent trends, questions and potential solutions. Science 320, 889-892.

Global Footprint Network. Accessed 2 June 2011, 〈http://www.footprintnetwork.org/ >.

Galli, A., Wiedmann, T., Ercin, E., Knoblauch, D., Ewinge, B., Giljum, S., 2011. Integrating ecological, carbon and water footprint into a "Footprint Family" of indicators: definition and role in tracking human pressure on the planet. Ecological Indicators. doi:10.1016/j.ecolind.2011.06.017.

Gorecki, K., Melcer, B., 2006. The effect of sewage treatment plants on nitrogen and phosphorus loads transported by the Warta River in the Oborniki-Skwierzyna Stretch. Polish Journal of Environmental Studies 15, 271-275. 
Kantor, L.S., Lipton, K., Manchester, A., Oliveria, V., 1997. Estimating and addressing America's food losses. United States Department of Agriculture Economic Research Service: Food Review.

Le Quéré, C., 2010. Trends in the land and ocean carbon uptake. Current Opinion in Environmental Sustainability 2, 219-224.

Miller, R.E., Blair, P.D., 2009. Input-Output Analysis: Foundations and Extensions, second ed. Cambridge University Press, Cambridge, UK.

Oenema, O., Witzke, H.P., Klimont, Z., Lesschen, J.P., Velthof, G.L., 2009. Integrated assessment of promising measures to decrease nitrogen losses from agriculture in EU-27. Agriculture, Ecosystems \& Environment 133, 280-288.

Organization for Economic Cooperation and Development. Accessed 27 June 2011, 〈http://www.oecd.org/document/3/ 0,3746,en_2649_34445_38071427_1_1_1_1,00.html >.

Raun, W.R., Johnson, G.V., 1999. Improving nitrogen use efficiency for cereal production. Agronomy Journal 91, $357-363$.

Sutton, M.A., Oenema, O., Erisman, J.W., Leip, A., van Grinsven, H., Winiwarter, W., 2011. Too much of a good thing. Nature 472 , 159-161.

United States Environmental Protection Agency, 2011. Science Advisory Board, Reactive Nitrogen in the United States: An Analysis of Inputs, Flows, Consequences and Management Options, EPA-SAB-11-013, U.S. EPA Science Advisory Board, Washington, DC.

United States Department of Agriculture: Center for Nutrition Policy and Promotion, 2002. How much are you eating? Dietary guidelines for Americans, Home and Garden Bulletin no. 267-1.

United States Environmental Protection Agency, 2005. National Emissions Inventory Data and Documentation. Accessed 10 June 2011. 〈http://www.epa.gov/ttn/chief/net/2005inventory.html $\rangle$.

United Kingdom Office of National Statistics. Accessed 21 October 2010, <http://www.statistics.gov.uk/about/methodology_ by_theme/inputoutput/ $>$.

UN Statistics Division, COICOP: Classification of Individual Consumption According to Purpose. Accessed 27 June 2011 , $\langle$ http://unstats.un.org/unsd/cr/registry/regcst.asp?Cl=5 $\rangle$.

Unie van Waterschappen, 2006. Clean Waste Water: National Comparison of the Regional Water Authorities with Respect to their Water Quality Management (in Dutch).

Wackernagel, M., Onisto, L., Bello, P., Linares, A.C., Falfán, L., García, J.M., Suárez, G.A.I., Suárez, G.M.G., 1999. National natural capital accounting with the ecological footprint concept. Ecological Economics 29, 375-390.

Wackernagel, M., Schulz, N.B., Deumling, D., Linares, A.C., Jenkins, M., Kapos, V., Monfreda, C., Loh, J., Myers, N., Norgaard, R., Randers, J., 2002. Tracking the ecological overshoot of the human economy. Proceedings of the National Academy of Sciences of the United States of America 99, 9266-9271.

Wiedmann, T., Minx, J., Barrett, J., Wackernage, M., 2006. Allocating ecological footprints to final consumption categories with input-output analysis. Ecological economics 56, 28-48.

Xue, X., Landis, A.E., 2010. Eutrophication potential of food consumption patterns. Environmental Science \& Technology $44,6450-6456$. 